\title{
The Making of a Marian Geography of Grace for Greek Catholics in the Polish Crownlands of the 17th-18th Centuries
}

\author{
Dieter Stern (ID
}

Citation: Stern, Dieter. 2021. The Making of a Marian Geography of Grace for Greek Catholics in the Polish Crownlands of the 17th-18th Centuries. Religions 12: 446. https:// doi.org/10.3390/rel12060446

Academic Editor: Dennis Ioffe

Received: 12 May 2021

Accepted: 9 June 2021

Published: 16 June 2021

Publisher's Note: MDPI stays neutral with regard to jurisdictional claims in published maps and institutional affiliations.

Copyright: (C) 2021 by the author Licensee MDPI, Basel, Switzerland. This article is an open access article distributed under the terms and conditions of the Creative Commons Attribution (CC BY) license (https:// creativecommons.org/licenses/by/ $4.0 /)$.
Faculty of Arts and Philosophy, University of Ghent, 9000 Ghent, Belgium; dieter.stern@ugent.be
Abstract: This article explores the ways in which the newly founded and highly contested Christian confession of the Greek Catholics or Uniates employed strategies of mass mobilization to establish and maintain their position within a contested confessional terrain. The Greek Catholic clerics, above all monks of the Basilian order fostered an active policy of acquiring, founding and promoting Marian places of grace in order to create and invigorate a sense of belonging among their flock. The article argues that folk ideological notions concerning the spatial and physical conditions for the working of miracles were seized upon by the Greek Catholic faithful to establish a mental map of grace of their own. Especially, the Basilian order took particular care to organize mass events (annual pilgrimages, coronation celebrations for miraculous images) and promote Marian devotion through miracle reports and icon songs in an attempt to define what it means to be a Greek Catholic in terms of sacred territoriality.

Keywords: Greek Catholics; Church Union; Ruthenia; popular baroque piety; Marian devotion; miraculous images; devotional songs; pilgrimages

\section{Introduction}

The veneration of images ${ }^{1}$ of the Mother of God and the belief in their miraculous powers have been key components of Christian spiritual practice since time immemorial, but they came to experience a particular boost in the age of the Counter-Reformation, when all kinds of devotional activities were fostered and reinvigorated in what looks like an effort of making a counteroffer of a more material religion to look at, touch and interact with as opposed to the bookish immateriality of the Reformation. It was meant to be an offer to the broad masses, as Counter-Reformation relied on mass mobilization to win back lost terrain. The entrance of the sacred into the material world of ordinary people required downsizing the sacred from its frightening cosmic oversize to more humane dimensions of ordinary sorrows and feelings of compassion. The Mother of God remodeled into a human impersonation of true motherhood would be the natural choice to win over the masses and reinvigorate trust in the church and state authorities. Piotr Hiacynt Pruszcz, a contemporary witness of the rise of Marian devotion and the proliferation of ever new Marian places of grace throughout the Polish-Lithuanian Commonwealth comments accordingly on the situation:

Zaprawdę, w Polszcze nászey nie mász Miásta, rzadka Wieś z Kośćiołem, w którymby się Obraz PANNY Nayświętszey nie ználazł cudowny. (Pruszcz 1662, p. 142)

Truely, in our Poland there is no town, and hardly a village with a Church of its own, in which there could not be found a miraculous image of Our holiest Lady.

What is true of Poland is no less true for the more narrow setting that we have chosen to have a closer look at, i.e., the Eastern, formerly a predominantly Orthodox part of the Polish Crown, that was claimed by the Greek Catholic Uniate church. ${ }^{2}$ In the confessional borderlands of the Polish-Lithuanian Commonwealth, the momentum of 
the counter-reformation was taken advantage of so as to also confront Byzantine-Slavic Orthodoxy. The Catholic attempt at winning over the Orthodox faithful by meeting them halfway with the promise of leaving orthodox spirituality and ritual traditions untouched brought forth Greek Catholicism as a confessional hybrid, which came to lead a life of its own through its efforts at asserting itself in a contested confessional terrain. In a parallel movement, both Roman and Greek Catholics made active efforts to secure their share of the confessional terrain quite literally in terms of spatial relations by construing geographies of grace for their respective flocks. Miraculous images were particularly suited to inspire a spatial sense of what it means to be a Greek or Roman Catholic by marking out specific places of grace, which through a complex array of ordered activities, supported by diverse kinds of hierotopic events (annual processions and pilgrimages, coronations), provided devotional objects (votive tablets, print reproductions of icons, commemorative medals) and minor texts distributed in print or handwritten copies (prayers, songs, litanies) for a lived experience of sacred space. This rematerialization of religious experience of folk baroque Catholicism could in the area in question capitalize on the deeply rooted traditional Orthodox conceptualization of the Church as "heaven on earth", in which "the Divinity is accessible through matter, that of sacraments and sacred objects", which "can be not only seen, but even smelled, tasted, kissed" (Fedotov 1946, p. 33). Though both Orthodox and Catholic traditions put an equally strong emphasis on the veneration of the Mother of God, the active reinforcement of the cult of miraculous Marian images in the PolishLithuanian Commonwealth in the 17th and 18th century ought to be seen as a particularly Catholic concern, which seems to owe much of its force and fervor to prior Protestant iconoclasm and its Hussitic precursor (Kruk 2011, p. 154). ${ }^{3}$ In times of confessional strife and competition, the potentials for securing one's flock by providing them with a sanctified geographical space to feel at home in could not be overlooked and was actively seized upon by Greek Catholics. ${ }^{4}$ Capitalizing on physical space and territoriality naturally implies linking up the sacred to the political, and indeed many practices and events around miraculous images openly reflect upon political and historical events and aim at making Marian devotion a foundational part of political power. ${ }^{5}$ In this paper we will outline how Greek Catholics organized a network of local, regional and supraregional Marian places of grace in order to gain a foothold in a contested confessional terrain in the face of their specific lack of a long-standing tradition of their own. Where Roman Catholics and Orthodox could lean back on an already established network of places of grace, Greek Catholics had to start from scratch (Jakovenko 2011-14). The acquisition and creation of places of grace as well as their successful advertisement were key to promote the loyalty of the community. ${ }^{6}$ Marian places of grace formed indeed the key constitutive element in the foundation of a Greek Catholic sacred space (Al'mes 2018, p. 266). On an as yet more fundamental level, a geography of grace founded on miracles helped also boost Uniate self-confidence in the face of external challenges to its right of existence, as the Uniate metropolitan Gabriel Kolenda clearly put it into words:

Evidentius argumentum probandi Unionem esse salutarem, et laudabilem non requiritur aliud, quam quotidiana miracula Beatae Virginis Zyroviciensis ( ... ). (EMKC n.d., p. 322)

There is no need for a more evident argument that proves the Union to be salutary and laudable, than the daily miracles of the Blessed Virgin of Žyrovyci.

The argument is quite straightforward. If the Church Union was against the will of God, he would hardly allow his graces to show up at Uniate places. Being able to boast an increasing number of miraculous sites could not fail to convince the faithful of the rightfulness and legitimacy of the Holy Union. Actively establishing a sacred geography is obviously a matter of acquiring and obtaining control over as many Marian sites as possible and successfully spreading the word of their miraculous powers. In a less obvious manner it is also about exploiting and reinforcing preexisting folk ideological notions about the relationship that holds between physical space and the sacred. It is our intention to 
demonstrate how interpretations of physical spaces as sanctified and thus meaningful places supported and orchestrated the rise of Marian devotion in a way as to help a specifically Uniate geography of grace to take root within the Uniate community. The underlying folk ideological notions of space and geography are most explicitly articulated in small text genres related to Marian devotion, in particular in miracle reports and Marian devotional songs in praise of miraculous images. We will build up our basic argument drawing primarily on these small text genres.

\section{Marian Places of Grace in the Ruthenian Lands}

Knowledge about Marian places of grace in the Ruthenian lands of the 17th-18th centuries is highly fragmentary and must be pieced together from a variety of sources. Despite the existence of a number of fairly extensive lists of Marian places (Baracz 1891; Fridrich 1904; Lužnyc'kyj 1984; Rožko 2002), it appears difficult to arrive at a complete list of all Marian places of grace that were known and applied to by the faithful throughout the period in question. In many cases, knowledge of the prior existence of a particular place of grace can only be derived from one source, which more often than not amounts to nothing more than a song in its honour. ${ }^{7}$ Lužnyc'kyj (1984), whose list is perhaps the most extensive, registers 114 miraculous images for the Ruthenian lands. He distinguishes miraculous ${ }^{8}$ from blessed images, the latter of which appear too numerous and knowledge about them too hard to come by to attempt an exhaustive list of them. ${ }^{9}$ It appears that the majority of registered images seem indeed to have gained public recognition for working miracles only within the period in question, while only few have a track record of working miracles since the middle ages.

In some cases, as in Pidkamin' or Boruny, ${ }^{10}$ the ground for establishing a place of grace was prepared through a grass roots tradition of reporting Marian visions that were unanimously interpreted as a sign to have a specific place of worship erected. When the place was established it was again the pilgrims who by simply coming in large numbers to the place and applying for help initiated the following step of calling in a commission to have the image officially recognized as miraculous. In the case of Pidkamin' it looks like it was the church authorities that were driven by the public to establish a place of grace, but the place would possibly never have acquired its fame without the commitment of the local Dominicans who applied to the bishop of Łuck, Andrzej Gembicki, to call in a commission in 1647, and it was the Dominican brother Szymon Okolski who painstakingly compiled the miracle reports obtained through the commission into a book that was published in 1648 (Rok 2005, p. 143). Often enough, as soon as a religious order or brotherhood took over, the reputation of an image's healing powers underwent a significant boost, as in the case of Krem'janec', which started to attract pilgrims only when the Augustinian Brotherhood of Our Mother of Consolation (Bractwo Najświętszej Maryi Panny Matki Pocieszenia) came in charge of the place in 1733 (Fridrich 1904, II, p. 382). The same can be observed anywhere, where Uniate Basilian monks took over. ${ }^{11}$ It can be reasonably assumed that Cholm, Počajiv, Terebovlja, Krechiv, Hošiv and Zarvanycja would have never risen to places of mass pilgrimage, were it not for the efforts taken by the Uniate church in the 18th century (Levyc'ka 2017-18). In the case of Žyrovyči, all started as early as 1621 at the founding congregation of the Uniate Basilian order. In 1622 a history of the miraculous image was published by Teodozy Borowik (Jakovenko 2011-14; Wereda 2018). In the course of the 18th century, Basilians had managed to provide in a targeted way for each church province a center of Marian devotion through applying for papal coronations: Žyrovyči for Lithuania, Cholm for the Polish Crown territory and Počajiv for Volhynia (Wereda 2018, p. 69).

The future fame of a miraculous image can, however, be initiated by a very modest first step indeed, as in the case of the exceptionally popular miraculous Mother of God at Sambir, which on being reported to the chaplain of the local parish church for shedding tears of blood in 1727, was immediately acquired by the priest from its private owner and put into place at his church to grant public accessibility (Fridrich 1904, II, p. 420). Within a very short time the image attracted pilgrims in significant numbers and within a year 
the Greek Catholic bishop of Przemyśl, Hieronim Ustrzycki, formed a commission to have the image officially recognized as miraculous. The tremendous speed of the events are suggestive of the energetic commitment of chaplain Andrzej behind it all, who appears to have been wholly bent upon establishing the fame of this image. Andrzej meticulously registered the weeping activity of the image for 175 successive days from September 1727 until May 1728, and he is also the one who composed a first person witness report on his discovery of the image (Fridrich 1904, II, p. 422). There are still other cases, where the solitary commitment of one or other private person sets things going, and in many of these cases, among them Sambir, one wonders if the image would have ever acquired any fame at all without the personal initiatives of these highly committed individuals.

\section{Indulgences, Pilgrimages and Pilgrims}

On the face of it, it should be obvious that news about miracles worked by images would spread fast among the population and attract in an uncoordinated and unorganized grass-roots process the afflicted and the suffering, yielding a steady flow of pilgrims over the course of a year. However, this is only part of the story. As a matter of fact, within the Roman Catholic tradition pilgrimages often combine two strains of intent, which though being somehow related, ought to be kept apart. Relief from actual suffering is the first aspect, while forgiveness of sins according to the Roman Catholic practice of indulgences, readily became an associated aspect. Wherever an image acquired the reputation of working miracles, the order in charge of the place was likely to channel the uncoordinated stream of supplicants into well-structured annual events by linking supplication to confession of sins and organizing regular mass events at fixed dates of the year for processions and pilgrimages of forgiveness (Pol. odpusty, Ukr. vidpusty). By extending the service profile of miraculous images to encompass indulgences, the entirety of the Catholic communities-Roman and Greek alike-were expected to visit at least once a year a miraculous image of their choice to obtain forgiveness for their sins. This practice was in an obvious manner designed to increase and reinforce public recognition and extend the range and significance of the place from the merely local into something bigger. This process of channeling supplicants into regular pilgrimages required official approval by authorities higher up in the ecclesiastic hierarchy thus putting the incipient and fluid spiritual grass-roots movement on a firm institutional footing in order to secure its long-term establishment.

A further side-effect of institutionalization is turning the private activity of individual supplication into part of a public event. ${ }^{12}$ The choice of the Basilian monastery of Žyrovyči to establish an institutionalized practice of pilgrimages about their miraculous image from 1625-26 onwards was by no means accidental. The place was singled out by Josip Veljamyn Ruts'kyj to become a major center of pilgrimage for Greek Catholics. This was achieved by obtaining an exceptional papal approval that pilgrims to Žyrovyči were granted indulgence on occasion of the Holy Year in 1625, which privilege was even extended to the following year 1626 (Senyk 1984, pp. 263-64). The monastery at Žyrovyči happened also to have been headed by Josaphat Kuncewicz, the only martyr of the Greek Catholic church, who was murdered in 1623 only three years prior to the establishment of the annual pilgrimage. There were plans, which became never realized, though, to transfer the relics of the martyr saint from their grave at Biała to the monastery at Žyrovyči, thus transforming the inconspicuous place of grace into the very geographical and spiritual heart of Greek Catholic confessional identity (Wereda 2018, p. 70).

Within the Greek Catholic confessional space the appointment of fixed days of the church calendar ${ }^{13}$ for common pilgrimages of forgiveness is attested for a significant number of miraculous images throughout the 18 th century. ${ }^{14}$ Making places of grace part of the practices of confession and forgiveness, which every believer had to undergo on a regular basis, could not fail to generate a mental map of grace within the consciousness of each and every Greek Catholic, which would comprise all places with officially approved pilgrimages and processions as its stable and immutable core, among which the coronated 
images would shine out as the most desirable destinations. For the Uniate metropolitan bishop Raphael Korssak it was a plain truth that a Marian geography of grace of one's own was a precondition on the emergence of a Uniate identity which he linked to Žyrovyči:

Capitaneatus et Districtus Civitatis regiae Slonim totus unitissimus, et si ubi, ibi habet S. Unio consolationem propter ecclesiam Zyrovicensem Beatissimae Virginis miraculosam, ubi sunt Monachi uniti. (EMKC n.d., p. 120)

The district and territory of the royal town of Slonim is totally Uniate, and if there is one place where the state of the holy Union is truly consoling, this is it, all on account of the church in Žyrovyči with its miraculous image of the Blessed Virgin, where there are Uniate monks. (translation quoted from Senyk 1984, p. 263)

Raphael Korssak's statement may be taken to be representative of the general train of thought among Uniate clerics. Confessional consolidation was made dependent on defining a sanctified territory, that might overlap with others (especially the Roman Catholic geography of grace), but which should also specifically cater towards the Greek Catholic community. Though on the face of it, miraculous powers and territoriality appear not to be intrinsically related, the specific practice of obtaining grace through miraculous powers as well as the legendary reports that frame them, are founded on folk notions of the miraculous that approximate physical materialism and are suggestive of miraculous powers being dependent on physical proximity and fixed places. The following section will provide an overview of the types of Marian miracles in order to be able to look into this issue more closely.

\section{Miracles and Physical Space}

There is a basic distinction to be made between (1) unsolicited miracles establishing the fame of the miraculous image by drawing for the first time common attention to its powers, i.e., founder miracles, and (2) miracles worked on a daily basis upon solicitation, i.e., through prior acts of supplication. Founder miracles do as a rule not predicate the type of service miracles that the image will work, once its miraculous powers have been established. Service miracles of type (2) can be further differentiated into (a) minor personal miracles (healing illnesses (Mater remedii), delivering the possessed by demons (salus infirmorum), support in personal crisis or distress (Mater auxiliatrix)) that require always personal supplication, (b) major miracles of politico-historical dimension (such as fending off military invaders) that combine both service and consolidation of fame. Miracles of type (2b) do not necessarily require solicitation, though prior instigation through mass supplication seems a common feature. Service miracles of politico-historical dimension may also serve to establish miraculous powers for the first time among believers, thus being at the same time founder and service miracles. Miracles of politico-historical significance are as a rule modeled on the famous Byzantine palladium miracle of the Blacherniotissa at Constantinople. Their prevalence on the Ottoman frontier of the Polish-Lithuanian Commonwealth throughout the 17th century thus draws on Byzantine-Slavic Orthodox traditions (Trajdos 1984, pp. 128-31).

It should be noted that founder miracles primarily focus on the image as an object of veneration for its own sake and are not meant to provide useful services to anyone. Thus, many founder miracles are not about healing and helping, but about stunning an unsuspecting observer by occurrences that go against the laws of nature. Quite common is the shedding of tears, which more often than not also serves as a comment on the deplorable state of affairs of the region in question. ${ }^{15}$ Typically, the threat to the integrity of orthodoxy ${ }^{16}$ through military attacks of heterodox forces will cause an image to weep. Perhaps it is no coincidence that weeping images made their first appearance on Ruthenian soil during the troublesome second half of the 17 th century. ${ }^{17}$ In the case of Počajiv the shedding of tears for a period of four weeks one year prior to the Turkish attack on the monastery in 1675 also brings into evidence the prophetic powers of the image (Przesławna 
gora poczaiowska Dawnością Cudow Przenayczystszey Bogarodzicy Panny od cudownego Jey Obrazu wynikających [1787] 1801, fol. 22r).

In some cases, unusual occurrences of a mystical and supernatural character serve as founder miracle. Thus, there are images which out of the blue make their first appearance in a tree (Žyrovyči, Kup'jatyči) ${ }^{18}$ in the woods (Staroduba) or on a river bank (Lin'kiv on the river Desna $)^{19}$ or just in the grass of a meadow (Ochtyrci). Their sudden appearance was likely to be taken as a sign of their supernatural origin as 'not being made by hand'

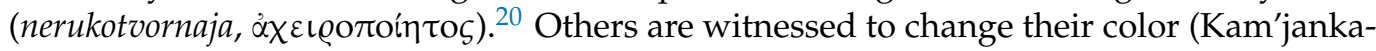
Strumylova) or to emit an unearthly light (Dubovyči, Ochtyrci, Počajiv). Still others publicly manifest their powers through being found unscathed by devastating fires (Nestanyč; Onyškivci; Zelenycja (later Rudky); see also Kruk 2011, pp. 173-80). These specific founder miracles may be assumed to serve as marks of distinction among the mass of miraculous images of local and supralocal significance. They moreover give testimony to the magical and spiritual texture of the natural universe of which the image forms part.

Founder miracles are not only meant to provide evidence of miraculous powers and to draw attention to a particular object of worship. They are also meant to establish authority, and doubting authority converts the healing powers into powers of destruction and punishment. The faithful are therefore not only to be comforted and kept in trust by an endless number of healing narratives, but they have at the same time to be warned and kept in awe of the supernatural powers. Rare but exemplary cases of renegades, heretics and unbelievers being severely punished for desecrating the place of grace and doubting its powers are therefore included in any miracle register. A particularly interesting case of a punishment is that of the miraculous image at the Basilian monastery of Puhinki, which raises a key issue of sacred geography. When the monastery at Puhinki was dismantled in 1840 following the abolition of the Union in those Ruthenian territories that came under Imperial Russian control, and the image had to be moved to another place, three villagers who attempted to remove it from its old place were struck by blindness, palsy and madness (Rožko 2002, p. 67). The punishment is obviously not so much about moving the image to another place, but rather about the destruction of its sanctuary and, accordingly, the destruction of its specific relation to space. It looks like miraculous images have a sense of physical belonging to a particular place. Thus images may be moved from their place in times of war and crisis, but this is only acceptable under condition that they will be moved back sometime later. If there is no intention of moving the image back to the place it has chosen for its miracles, the image may even stop its miraculous activity, as in the case of the image of Počajiv that did not show any signs of miraculous powers during its period of sequestration at the hands of Firlej Bełzki from 1617 to 1647. When the image was restored to its original place, it started working miracles again (Przesławna gora poczaiowska Dawnością Cudow Przenayczystszey Bogarodzicy Panny od cudownego Jey Obrazu wynikających [1787] 1801, fol. 9r-11r). The movement of images to better equipped places in the near surroundings poses usually no problem, though. The image of Pidhirci professed its first miracle at Holubycja in 1692, from where it was moved to the nearby Basilian monastery at Pidhirci in $1694 .{ }^{21}$ Likewise, the miraculous image of Rudnja was moved to the Ascension monastery in Kiev to give it greater prominence, without this movement impairing her miraculous powers in any way (Senyk 1984, p. 265). On the contrary, the new abode at the Kievan Cave monastery was expected to provide for a better environment which could not fail to enhance even the image's miraculous powers, as an early song in praise of this image states:

V obiteli panjanskoj, pri cerkvi Pečarskoj,

$V$ chramě svoemъživetъlěpšsvesi Rudjanskoj.

(ms. ASP 135, fol. 63v, v. Hruševs'kyj 1897, p. 49)

In the nunnery, close to the Cathedral of the Cave,

in a chapel of her own she [scil. the image] lives better than at the village of Rudnia. 
Miraculous images seem to choose the place where they work; their miracles are not random. When the village of Nestanyč (Galicia) was burnt down in a Tatar raid, the image at the local church which was found unscathed by the fire and was ordered to be brought to the church at nearby Stanyn, but the cart-horses would not move and when forced to do so, would return to Nestanyč (Lužnyc'kyj 1984, p. 177). ${ }^{22}$ Though places are not chosen randomly, it is only rarely that the actual reason for selecting a particular place is made known. When Franciscans, who had heard of the miracles worked by the image at the Basilian monastery at Žyrovyči, made plans to acquire the image and move it to their own monastery, God explained to one of the Franciscan brethren in a dream vision, why the image must not be moved:

$(\ldots)$ et intellexit hunc locum pro defensione et promotione unionis a Deo excitatum atque ablato unitis loco miracula cessatura.

(Harasiewicz 1862, p. 342)

(... ) and he understood that this place had been chosen by God for the defense and promotion of the Union, and that if [the image] were to be taken away from that Uniate place, the miracles would stop.

It is perhaps not by accident that an explicit motivation is provided in this particular case, where confessional politics of place come into play. As we have seen above, Žyrovyči was indeed intended early on to become the very center of Uniate identity, and losing its miraculous image must have thwarted the Uniate politics of building up a confessional territory of its own.

The principally indissoluble link between image and place implies also a particular loyalty of the image to its place, which is iconically expressed in narratives of defending places of grace against military invaders, as most prototypically represented by the Hodegetria of Constantinople (Blacherniotissa) spreading the palladium (omofor) over her wards. It is through these miraculous appearances that images are awarded the name of the place as their specific cognomen, yielding titles typically found in the rubrications of icon songs such as Bogorodica čudotvorna počajevska and the like. Kruk (2011, p. 166) observes that through the palladial function of the Mother of God as mater misericordiae the according naming practice of local identities was created, reinforced and maintained. ${ }^{23}$ The intimate and indissoluble relation to a place of its own seems to be expressed as a territorial ownership of sorts in the workings of miraculous images, especially frontier icons that on the face of it appear to defend the local populations against military invaders, but ultimately aim at maintaining the integrity of the sanctuary which hosts the image and delimits its spiritual dominion, which includes the local population as its integral part. Perhaps, the footprints left by the Mother of God in her visionary appearances at Počajiv and Pidkamin' should accordingly be read as ownership marks. There could not possibly be a more lasting material testimony to the strong territorial bond into which the Mother of God has entered. Počajiv and Pidkamin' appear to be marked out by these footprints as being held in greater esteem by the Mother of God than any other place she owns. The working of miracles through images turns the arbitrariness of physical space into the uniqueness of a meaningful place. By relating the sacred to the physical, the foundation for territorial identity is laid. As each miraculous image has a place of its own, everyone who enters into a relation with it becomes somehow part of the geographical space it defines.

\section{The Materiality of the Sacred, Communication and Personhood}

The paradox of the manifestation of the sacred which is not of this world, in objects of this world has been remarked and commented upon by Mircea Eliade (1957, pp. 8-9). It becomes particularly apparent in the practices and beliefs growing around the working of miracles, which bring forth and are supported through material objects, such as images. In an obvious way, it is unavoidable that the sacred turns into material objects in a world of physical matter by the simple act of referring to it. Eliade's amazement is, however, not so much about the semiotic relationship between the material signe of sacred objects and 
the immateriality of the sacred as signifié. In fact miraculous images are not conceived of as signs (be they symbolic or iconic in the Peircean sense), but they seem to have been believed to actually be what they represent: "The saints were really present in their relics as well as in their icons" (Fedotov 1946, p. 33). ${ }^{24}$ Mere representations could not be hurt and bleed and weep like miraculous images do. As a matter of fact, in a song in praise of the Mother of God at Kam'janka-Strumylova the miraculous image is being depicted as an actual face that reacts to the supplicant:

Tvarıbo izměnjaetъ, slezy izlivaetъ, sklanjaetъušesa, priemletъslovesa.

(BG 2016, no. 131)

Her face changes, she starts weeping, she lends her ear and takes in the words.

Once, however, personhood is assigned to images, the sacred tends to become locked in into the world of matter and thereby acquires a spatial dimension. Physical space thus turns into a meaningful place through its association with sanctity. As a matter of fact, the close, ownership-like link between place and image, discussed above, bears directly on the issue of personhood. By assigning an image to a fixed place, the image may up to a certain degree achieve independence of the higher abstract personhood of the biblical figure of the Mother of God as such. Having a face of its own that can weep, a body that can bleed, and being indissolubly related to an individual place in an ownership relation of sorts are the basic ingredients of individuality and personhood. Through the proliferation of miraculous images, the mother of God seems to turn into a multiplicity of Mothers of God, the more so where images enter into competition with each other (on which see below). ${ }^{25}$ The Mother of God of Počajiv would then in a very immediate sense not be the same person as the biblical Mother of God, whatever else their relationship may be. This folk ideological interpretation could not fail to make theologians feel uneasy about the cult of miraculous images and to ultimately inspire iconoclastic thinking. There is, of course, no way of knowing if individual worshippers perceived images as true persons, but there is at least one Marian song that favors Surožskij's interpretation of the Mother of God being present and acting through the icon without becoming the icon:

Inši kto žъtvoi čudovny obrazy

zličiti može panien'ko bez zmazy,

v kotorychъesъvel'mi južesъsja vslavila

i rozmaitychъlaskъljudъnabavila.

(Kamjanskij Bogoglasnik 1734; cf. Žeňuch 2006, p. 908)

And who is capable of counting

all the other miraculous images,

in which you have acquired fame

and proffered variegated graces to the people.

This stanza may possibly reflect an attempt to maintain the official high church interpretation in the face of problematic grass roots tendencies.

Miraculous images grant unmediated access to the sacred for the supplicant who can speak to the sacred and touch it—especially by kissing as a mark of respect-but also to induce the sacred to flow over to the supplicant upon the touching of the image. The latter aspect becomes yet more apparent in less common forms of the material manifestation of sacred powers, as in the case of healing water (Počajiv, Pidkamin', Univ, as well as a number of minor places of grace in Ruthenia, such as Nastašiv). For healing water to become effective, physical application to the sufferer is indispensable. As we have seen, restrictions on physical space also apply to the working of miracles. Miraculous images are bound to a particular place through their founder miracles, and the same 
is even more obviously true of healing water. In order to overcome the restrictions of physical space techniques of replication and transfer have to be applied. Thus the healing water at Počajiv was taken home by pilgrims in small bottles (Rožko 2002, p. 82), in order to be applied whenever and wherever needed. The same holds for images, which can be made miraculous through the simple technique of rubbing them against an already miraculous image, as in the case of the image of Nastašiv which is said to have acquired its healing powers through rubbing it against the Black Madonna of Czestochowa (Baracz 1891, pp. 189-90; Fridrich 1904, II, p. 263; Stern 2000, p. 36). ${ }^{26}$ It may be assumed that the sanctification through the physical act of rubbing was quite common and also applied to minor objects as print reproductions of famous images and small figurines of the Mother of God, which could be taken along wherever one went. ${ }^{27}$ This all looks as if the sacred was conceptualized as a kind of invisible, but ultimately material property of this world, as a kind of electric energy of sorts that prefers particular configurations of the material world to manifest itself as effectively as possible. There is here a general danger of the profanation and ultimate dissolution of the sacred into an utterly materialist perspective. This is, though somewhat lamely, counteracted by the requirement that successful treatment depends on a spiritual attitude which creates a personal relationship between the supplicant and the sacred through the medium of material objects.

Imagined pilgrimages, as suggested by Chociszewski (1882, p. 106) are suggestive of an immaterial and placeless, apparently purely spiritual interpersonal, communicative relationship, though true physical experience still looms large in this exceptional practice. Moreover, the interpersonal relationship rather than counterbalancing the materialism of the physical experience of pilgrimage and acts of supplication, is itself liable to bring about profanation, especially where the sacred becomes impersonated, as is most obviously true of the veneration of the Mother of God. Marian devotional songs show a common strong tendency to emphasize the role of the mediatrix who can be applied to like any person of influence of the material world. Among Marian songs, icon songs carry this tendency to the extreme. The impending profanation of the interpersonal relationship is counteracted not so much by the sanctity of the mediatrix, but by the sanctity of the suffering brought to her witness. As soon as the mediatrix is applied to for minor causes where suffering in the commonly accepted sense of the word is not involved, the sanctity dissolves altogether and the supplication turns into a grotesque. ${ }^{28}$

In most cases the procedure and basic mechanism of obtaining a miracle would be quite obvious. Miraculous images were addressed as directly as possible by either praying in front of them or, if possible, even touching them. It looks as if some kind of face-to-face communication has to happen before the Mother of God will take up the case for the supplicant. The image appears to serve the function of a communication device. Possibly it is even considered as a personal living being in its own right, as is suggested by the lines quoted above about the Mother of God of Kam'janka-Strumylova. These lines reinterpret the topical miracles of shedding tears and changes of appearance, reported for so many images as founder miracles, as actual facial expressions. Where the sacred is conceived of as personal, there is a direct pathway to its being made present in the material world. Relating to the sacred means entering into an interpersonal relation, which implies communication. All communication needs a medium, which in this world must needs be physical in kind. In order to say your prayers, words should be audibly spoken, and ideally there ought to be someone visibly present to be spoken to. Thus, images allow for a greater approximation of natural face-to-face interaction, but still communication appears to remain a one way road of sorts, where the image usually will respond only indirectly through performing or refusing to perform a miracle. It is only through weeping, as the lines about the Mother of God of Kam'janka-Strumylova so vividly show, that the sacred can take directly perceptible, physical action that can be interpreted in terms of a communicative act in the sense of Hymes (1972). In fact, weeping will be regularly interpreted as a comment on recent deplorable events, mostly of a politico-historical dimension, such as the frequent Tatar and Ottoman raids and military expeditions. It can be more generally taken as an admonition 
to the faithful to reconsider their moral behaviour and redirect their steps, as in Wespazjan Kochowski's lines:

Te oczy płaczą Matki naszej drogi

Dla upomnienia nam i dla przestrogi. (quoted from Kruk 2011, p. 267)

Those dear eyes of our Mother keep weeping,

for us to remember and as a warning.

However, contrary to what the lines from Kam'janka-Strumylova suggest, this is still a far cry from face-to-face interaction. Sacred communication in physical space still remains a monological one-way road, though it may change directions at times.

From the long row of miracle reports from Počajiv it can be gathered that ideally the diseased should be present in person in front of the image, even if he or she is incapable of offering a prayer and needs someone doing it in his stead. Thus, several miracle reports provide details on how even the fatally ill were transported over long distances in order to place them in a lying position in front of the miraculous image. If the place was known for highly potent healing powers, even people who were believed to be dead were presented in this way. ${ }^{29}$ This looks like the Mother of God would require some visual evidence before granting her support and that she can perceive this evidence only through the miraculous image, as if it were her eyes on earth. Whatever conceptualization of the mechanical laws and requirements of miracles may stand behind this, supplicants must have believed that effective help was less reliably obtained through an intermediary with the person in need of help being absent. In contrast to what appears to be the common practice at Počajiv, many supplicants at Pidkamin', however, followed a less strict and troublesome procedure. If the needy person in his disease was unable to visit the place of grace in person, he would send a donation in order to apply for help and would visit the place afterwards to bring his votive in person to the image. ${ }^{30}$ The reasons for this marked difference in practice can only be guessed at. On the face of it, the practice observed at Pidkamin' contradicts to some degree our assumption that the working of magic is bound to a particular place and requires face-to-face interaction. The practice does, however, not downright deny the precondition of the uniqueness of place, but makes only allowances for a more supple and practicable interpretation, by postponing face-to-face interaction to a later point in time. The offering of votive tablets in these particular cases is then not only a sign of gratitude, but restores the spatial order of magic.

General instructions for the supplicant on how s/he ought to physically approach a miraculous image is also provided in some song texts, as in the following stanza:

Podźmy przed obraz Maryjej,

Tej najśliczniejszej lilijej,

Poklęknąwszy, rączki słożmy,

Do jej się nożek ucieczmy.

(quoted from Kruk 2011, p. 214)

We come to stand in front of the image of Mary,

that most beautiful lily,

and, once we have kneeled down, we fold our hands,

and we seek shelter below her feet.

These instructional verses can be taken to depict a standard manner of approaching an image, possibly even a recommended form of behavior that is meant to prevent the masses of supplicants from engaging in too intimate a manner (such as touching and kissing) with the miraculous image that must inevitably cause wear marks in the long run. Apart from these more practical worries, an overly intimate relation allowing for direct physical contact would also run counter to the idea of a celestial hierarchy, which according to Catholic notions would turn the Mother of God into the Queen of Heaven. The imposition of a 
modicum of spatial distance would then serve to maintain the hierarchy and dividing line between the sacred and the profane. As Erazm Gliczner's report suggests, pilgrims seem indeed to have been instructed by chaplains of what to do (and possibly also what rather not to do) in front of a miraculous image, which in Gliczner's protestant eyes is already too much:

I zwłaszcza że liud prostiy z nauki Kapłanow Kościoła Rzimskiego nauczeł się y uczy przed Obrázmi ták ritemi bałwany táko y málowánimi kłaniać y klękać y klęczac swe modlitw przed nimi mowić szapke zeimować y insze nabożne pokłony czynić, swieczky przed nimi zápalene stawiać, Krzyżem padać, lieżeć \{... \} (Gliczner 1598, fol. 51v)

And the common people were indeed instructed from the knowledge of the Roman Catholic chaplains and learned to bow and kneel down in front of the images, be it sculpted figures or paintings, and once they kneeled down, to say their prayers in front of them and to take off their hats and do other kinds of pious exercises, and to put burning candles in front of them, and to prostrate and stay lying in the form of the cross (... ).

All actions listed restrict the interaction between supplicant and image to the level of mere perception over a certain physical distance. This distance was often imposed by the spatial arrangements of the sanctuary. As a matter of fact, the more famous an image became, the more prominent a location it was assigned in its sanctuary. The more famous images were, as a rule, put up in a shrine behind the main altar (Kruk 2011, p. 216), which effectively precluded any form of intimate interaction, thus thwarting the folk ideological idea of physical contact as a precondition for miraculous powers to become effectively operative. Putting images in side altars and specifically designed chapels allowed for a more private and secluded form of supplication, to be sure, but it would still not allow for physically intimate forms of interaction. ${ }^{31}$

The modest offerings of votive tablets for individual help combine with monumental celebrations, the building of chapels and altars and the donation of rich adornments to create a space of worship and devotion that fuses both acts of individual gratitude and the display of political power through its link to the sacred to yield a meaningful place that ultimately transcends the division between the private and the public. The latter aspect becomes particularly evident in the practice of coronations. Coronations of miraculous images and the pompous ceremonies associated with them can be seen as the culmination and ultimate completion of the general trend for visualizing and sensualizing spiritual experience within the framework of fully developed 18th century Catholic baroque culture. $^{32}$ Moreover, the very imagery of a coronation clearly implies a parallelization of sacred and secular power. The coronated icon is quite obviously the visible representation on earth of the regina coeli, who enters into a specific political territorial alliance with the Polish-Lithuanian Commonwealth as the Most Holy Virgin Mary, Queen of Poland (NMP Królowa Polski). ${ }^{33}$ Coronations of miraculous images became a fashionable competition in Ruthenia (Levyc'ka 2017-18), which was set going by the coronation in 1717 of the Black Madonna of Czestochowa. Only a decade later two more sites applied almost simultaneously for papal coronations, one being Basilian (Žyrovyči 1726/1730) and the other one Dominican (Pidkamin' 1727). The celebrations were usually organized as ecumenical events (addressing Roman, Greek and Armenian Catholics) and attracted tens of thousands of faithful. They were put on stage with great pomp, including the declamation of elaborate sermons on Marian topics, public disputations on theological issues, artful fireworks, that lasted for hours and depicted various pertinent symbols and images, the erection of triumphal arches, the artful illumination of buildings, concerts, military parades, canons firing salutes, the exposition of historical paintings commissioned for the occasion, the issuing of commemorative medals by the thousands. The celebrations were in an obvious manner meant to excite all senses and to turn Marian devotion into an overwhelming experience of joy that did not shun forms of entertainment that must strike 
a modern observer as carnivalesque and almost profane, but which were described in all detail with obvious pride in commemorative volumes that were laboriously compiled and issued years after the celebrations. ${ }^{34}$ Enthusiastic mass excitement and mobilization was the key objective of these celebrations, which is most vividly illustrated by the manner in which the commemorative medals were distributed among the attending masses. Instead of giving the medals individually to anyone who wanted one, they were thrown by the handful among the masses (Rok 2005, p. 146). The multi-layered structure of these events testify to a monumental enactment of the power of a self-confident unified Catholic church that is firmly anchored in this world and does not shy away from publicly displaying its close links to secular power. The sacred alliance of clerical and secular power is visibly reflected in the patronage of coronation events, which are represented in portraits on the scene of the celebration. In the course of the coronation celebrations at Počajiv 1773 on the walls inside the monastery cathedral paintings of the Polish king Stanisław August Poniatowski and the local patron and donor Mikołaj Potocki were opposed to paintings of pope Clemens XIV and bishop Sylwestr Rudnicki (Wereda 2018, p. 74). The unity of sacred and secular power is further underlined by paintings commemorating historical events within the confines of the monastery, as in the case of the coronation at Cholm. The presence of a tremendous number of ordinary citizens gives proof to the general alignment of popular, political and clerical will. It goes without saying that an event of this kind and size could not fail to kindle ambitions among all monasteries throughout the Ruthenian lands. Počajiv which vied for regional primacy with Pidkamin', with which it shares the prominent feature of combining a miraculous image with an additional pond of healing water, could not fail to do its utmost to have a coronation of equal dimensions as the earlier one at the Roman Catholic (Dominican) monastery at Pidkamin'. ${ }^{35}$ It is not known, how many faithful attended, but the expense made was similar. In one point Počajiv managed to outscore Pidkamin' by having 5 instead of 4 triumphal arches at its coronation festivity.

\section{The Geography of Grace According to Ruthenian Devotional Songs in Praise of Images}

Minor texts such as witness reports on miracles as well as devotional songs in praise of individual images contributed in an essential manner to the construal of a specifically Greek Catholic Marian landscape, but they did so in different ways. ${ }^{36}$ Both text genres conveyed information about miracles and the places where they occurred in sufficient detail so as to build up and mnemonically maintain the collective consciousness of sanctified space throughout the Greek Catholic community. This referential function, important as it is by itself, was, however, implemented and expanded in widely different ways. Witness reports may be supposed to have started as orally transmitted tales that spread through the untraceable channels of gossip and rumor in an undirected and uncoordinated manner. At this early stage, there may have been little enough political intent at play to help confessional identity building. With the documentation, collection and publication of these tales in written form things take a more political turn that clearly aims at engrossing the as yet confessionally unmarked miracles for the benefit of one's confession, but is is doubtful that miracle reports in written form had a direct impact on the collective memory and consciousness of the community. Songs, however, are likely to have been composed right from the start with the intent to draw public attention to the place in question and enhance its significance within the community. Their communal role is played out by making them part of the lived bodily experience of sanctified space through singing them or just listening to them on one's way to the miraculous image as well as on the spot, in group or individually. ${ }^{37}$

Icon songs dealt in various ways with their objects of praise. If there was not much to be said or little known about the image and its miraculous history, songs would take the form of a common and unspecific Marian doxology which would be rounded off by an unspecific stanza of general supplication. Most songs, however, try to convey more specific knowledge about the image in question. Two basic types can be observed: (1) narrative songs reporting on founder miracles (this is preferably made use of if the founder miracle is 
of a politico-historical dimension, such as fending off Ottoman aggression), (2) advertising songs providing lists of ailments that are cured and examples of historically attested spectacular healing successes. It goes without saying that songs can and often do combine both types. Thus, a song in praise of the miraculous image at the Dominican monastery at L'viv offers the following treatments:
Mertvyja voskrešaešъ,
Čelověkъot běsovъuvolnjaešъ, i ot bědnychъljudej febry otganjaešъ,
You raise the dead to life again,
You deliver people from demons, you chase away fevers from the poor, you make the blind see again. slěpychъprosvěščaešъ. (ms. Maslov 54, fol. 30r; cf. Hnatjuk 2000, p. 197)

Generic types of wonders are advertised in a sober, matter of fact fashion, sometimes awkwardly phrased owing to the requirements of rhyme and meter, as in the case of the healing miracles worked by the image of Zahoriv:

Umarli wstaią na Twe załowanie,

Dziękuią chromi za wyskakiwanie. (BG 2016, no. 118)

The deceased stand up at your command, the lame thank you for [their] jumping up.

It is remarkable that in many cases only few words are assigned to praising and mentioning the miracles themselves. The larger part of any song usually consists of common doxological set phrases. This nonspecificity is in line with the practice to adapt songs from better known miraculous images. ${ }^{38}$ Advertising can also include references to the sheer masses of pilgrims that are being attracted, as well as to the fact that pilgrims come from faraway places and that some of them belong to the higher strata of society (noblemen and kings).

An estimated amount of some 100 to 150 different devotional songs referring to Marian places of grace may have been circulating within the Ruthenian lands (Medvedyk 1999; Medvedyk 2015). The first songs of this kind were composed already in the second half of the 17th century (Medvedyk 2015, p. 372), but the vast majority of them date from the 18th century. Devotional songs were primarily disseminated in private manuscript song collections, and only exceptionally in print. As the area of Greek Catholic activities was by and large bilingual, songs in praise of miraculous images of that region may be either in Ruthenian, which was the common majority language, or to a somewhat lesser extent in Polish, as the language of learning and of the higher classes (and increasingly of the Basilian order). Some images were honored by songs in both languages. Though it is almost impossible to pin down the exact origin for any Ruthenian devotional song, it is generally assumed that many if not most of them were composed by Basilian authors. ${ }^{39}$ As for icon songs, there is an obvious bias for Greek, and to a lesser extent Roman catholic sites. Famous orthodox miraculous images like at the Kievan Cave monastery or Černihiv attract fairly little attention of song writers, though, it has to be admitted that one of the earliest icon songs was composed in praise of the image of Vyšhorod, that was translated to Kiev in $1662{ }^{40}$ As a matter of fact, only Basilian monks cared to prepare print editions of Ruthenian devotional songs, most notably the Bogoglasnik of Počajiv of 1791 (BG 2016). Moreover, a closer look at the places of grace represented in the repertoire of Ruthenian devotional songs shows a very pronounced bias for Basilian sites. Thus, it can be safely assumed that Ruthenian devotional songs, though they are in no way openly confessional in their contents, convey a Uniate, or more specifically a Basilian perspective.

Among the 114 images registered by Lužnyc'kyj (1984) for the Ruthenian lands, less than a quarter (26) are specially honored by songs. Our own estimate ${ }^{41}$ of the number of 
images being praised in Ruthenian devotional songs yielded 39 locations. ${ }^{42}$ To these may be added a number of 9 images for which devotional songs in Polish instead of Ruthenian have been composed. ${ }^{43}$ It goes without saying that the more popular an image, the more likely it will be honored by a song, with the most popular sites such as Počajiv being honoured by a fairly large number of songs. ${ }^{44}$ As for the lesser known images there is no way of telling what made a song composer select them, but it can be assumed that Basilian interests stood often behind the decision to have a song composed for a particular image. ${ }^{45}$ In the case of the icon songs assembled in the Bogoglasnik there is no getting around the impression that the icon songs for Basilian sites authored by Basilian authors were at least in part specifically composed for the edition of the Bogoglasnik in order to bring into focus the wealth of the Basilian geography of grace. ${ }^{46}$ At least some of the songs in praise of the select few coronated icons may be assumed to have been composed on the occasion of a coronation with the intention to sing them publicly at the festivity (Kruk 2011, p. 268). ${ }^{47}$ Especially, songs that make their first appearance in the years after the coronation may be rightly assumed to have in fact been composed for the occasion. It can be assumed that songs were composed to serve the needs of regular ritual devotional celebrations of a paraliturgical kind, such as annual processions, rosary devotions and the like. In fact, any miraculous image that came under the patronage of a brotherhood or a religious order was likely to become the object of organized worship (Kruk 2011, p. 269), which would include prayers and songs. On occasion, songs seem to have been composed by individuals to commemorate a plight which the author experienced personally and through which the author desires to express feelings of gratitude for having survived the plight. This is apparently the case with the two songs in praise of the Mother of God at Sambir, composed by Andrzej Jakubiński in October 1770 right after the epidemic of that same year (Ščurat 1908b, pp. 181-85). Other songs were composed on the occasion of a translation to a newly built sanctuary, as in the case of the song Drogi klejnocie naroda ruskiego (Al'mes 2018, p. 272).

For songs to be able to shape the Greek Catholic geography of grace they should ideally be disseminated in large numbers, and in addition dissemination should also be directed and coordinated in order to avoid undesirable outcomes. However, up to the end of the 18th century, when the Bogoglasnik, a large print collection of Ruthenian (and a smaller number of Polish) devotional songs, was published at the Uniate monastery of Počajiv, devotional songs were almost exclusively disseminated in highly individualized manuscript collections, some of them possibly compiled and arranged by Basilian monks, ${ }^{48}$ but most of them appear to be private collections that were randomly compiled. Prior to the publication of the Bogoglasnik, there were only few editions of commemorative volumes in praise of individual images that contained a small number of icon songs. ${ }^{49} \mathrm{~A}$ further possible source of dissemination, which is for the time being difficult to assess, are print reproductions (wood cuts, etchings) of miraculous images and sites that seem to have been provided with texts of devotional songs, akathists or other liturgical hymns, at least in a number of cases (Levyc'ka 2017-18).

Song collectors included in their private collections not only icon songs from their home region, but often display an interest in Marian places of grace from all over the Ruthenian lands. Thus, song collections originating from Transcarpathia regularly register songs from other Ruthenian regions of the Polish-Lithuanian Commonwealth, such as Galicia, Volhynia, Podolia, Polesia and Kiev, and occasionally even include places from geographically as well as politically quite remote Slobozhanshchyna, such as Kaplunivka (Medvedyk 2015, p. 371), thus creating a sense of cultural-geographic belonging beyond the confines of one's immediate home region..$^{50}$ On the whole, Ruthenian collections of devotional songs display, however, a clear focus on Galicia and Volhynia, identifying these as the heartlands of Greek Catholic Marian devotion. The vast majority of song collections register only icon songs for one or two sites, with a clear bias on Pidkamin', Počajiv and (Novyj) Sambir, which three places figure also prominently in the remainder of the manuscripts that register a larger number of sites. 
It is not quite clear if the choices made in song collections reflect the personal history of pilgrimages of song collectors, as is insinuated by Pap (1971, p. 119). There is at least one observation that would speak against such an assumption. Longer lists, of up to 7 different Marian sites are usually found in collections of a larger size. A strong correlation with the overall size of collections would be suggestive of the number of sites reflecting the collecting activity rather than the actual pilgrimage history of the collector.

If we assume that the choice of icon songs in private manuscript song collections somehow reflects the common popularity of Marian sites of pilgrimage, then the most often attested sites would represent the core sites on the Greek Catholic mental map of grace. Interestingly enough, the list of the sites most often included in song collections is headed by the Roman Catholic (Dominican) sanctuary at Pidkamin', followed by the Basilian sites at Počajiv, Sambir and Bar. ${ }^{51}$ Most remarkably the declared center of Uniate Marian piety Žyrovyči, as well as the famous and time-honored Marian site at Cholm do not show up at all in song collections, despite the tremendous investments and efforts of the Basilian order to popularize these sites. The assumption that no songs were composed and published for these images is highly unlikely in view of the fact that for both sites coronation celebrations were held, which implies the composition of songs of praise. ${ }^{52}$ The question, however, remains what has become of these songs? Why did they not become sufficiently popular to survive into our age? There can be no doubt, though, that both sites attracted huge numbers of pilgrims each year, so that, though the existence of icon songs and their dissemination in song collections may tell us something about the main sites on the Greek Catholic mental map of grace, the lack or absence of icon songs tells us little enough about the relative significance and publicity of any Marian sanctuary. The reconstruction of the mental map of grace of 18th century Greek Catholics would thus necessarily remain incomplete, were it to rely exclusively on the presence of icon songs in song manuscripts. There are still other famous Uniate Marian sites, such as the Lavra at Univ, for which no songs can be identified in manuscript song collections. The particular circumstances and reasons why no songs for these obvious candidates of praise have come down to us can only be guessed at. The simple and straightforward assumption of a documentary gap, i.e., the assumption that there might have been dozens of copies of the respective songs which somehow did not survive into our age, cannot offer a convincing answer. If there ever were songs in praise of these images, they must be assumed to never have attracted the common interest of song collectors. Since we know little enough about what guided collectors of devotional songs in selecting and compiling their personal song treasuries, we are unable to provide an answer for this intriguing question, and it looks like we will be never able to come up with an answer. ${ }^{53}$

\subsection{Geographical Hierarchies}

All icon songs that we analyzed reveal a common pattern of relating grace to geographical space, which reproduces patterns of hierarchically nested geographical entities. The highest level is defined by the universal orbis christianus. On the next lower level the Polish Crown is regularly identified. Interestingly enough, hardly any songs make reference to the Polish-Lithuanian Commonwealth. Instead, some songs refer to the cultural area of 'Russia' (Rossija or ruskij kraj in the songs), i.e., the Ruthenian lands, which form part of the Polish Crown. On the next lower level, the administrative region (e.g., Volhynia, Podolia) or even district (Polish powiat) is referred to. Though the regional level is usually identified in terms of administrative units, it can exceptionally be identified in more volatile and diffuse terms of a specific plight. Most prominently the most heavily afflicted places on the Ottoman frontier are conceived of as a region in their own right. ${ }^{54}$ Regions can be defined even more ephemerically in terms of having been afflicted by an epidemic in the more recent past. ${ }^{55}$

The universal dimension of the totus orbis christianus is employed only very sparingly to mark off those places of grace that have gained the highest degree of celebrity. The capacity of an image to attract pilgrims from far beyond the immediate local or regional 
surroundings was made a requirement for a miraculous image to qualify as a candidate for a papal coronation (Levyc'ka 2017-18). Reference to the world at large is therefore likely to be found in songs for icons that have already been coronated as an epithet of honour and entitlement. In the songs we investigated it was mainly the songs in praise of Počajiv (e.g., BG 2016, nos. 111-14) that regularly alluded to the Christian world at large in such expressions as vselennyja vsja strany 'all countries of the inhabited world', pojušče vsja strany 'all countries sing', svidětelstvuet ... blagodat s tvoju i po cělom světě 'your grace is borne witness to all over the world'. Only few other images are praised for attracting pilgrims from all directions, and it can only be surmised that reference to pilgrims from far away was possibly introduced into song texts with the aim of preparing a coronation procedure. ${ }^{56}$ The politico-historical dimension of miracles is commonly addressed by referring to the national and immediately subnational level of geography. Thus, with an obvious reference to the Marian epithet of Queen of Poland (NMP Królowa Polski), established by king Jan Kazimierz in 1656, many icon songs relate miraculous action to the lot of the Polish Crown, as in one of the songs in praise of the Mother of God of Počajiv Veselo spěvajte, vsi čelom vdarjajte, which depicts the intervention during the Ottoman crisis of 1675 as an act meant to save the entire Polish nation:

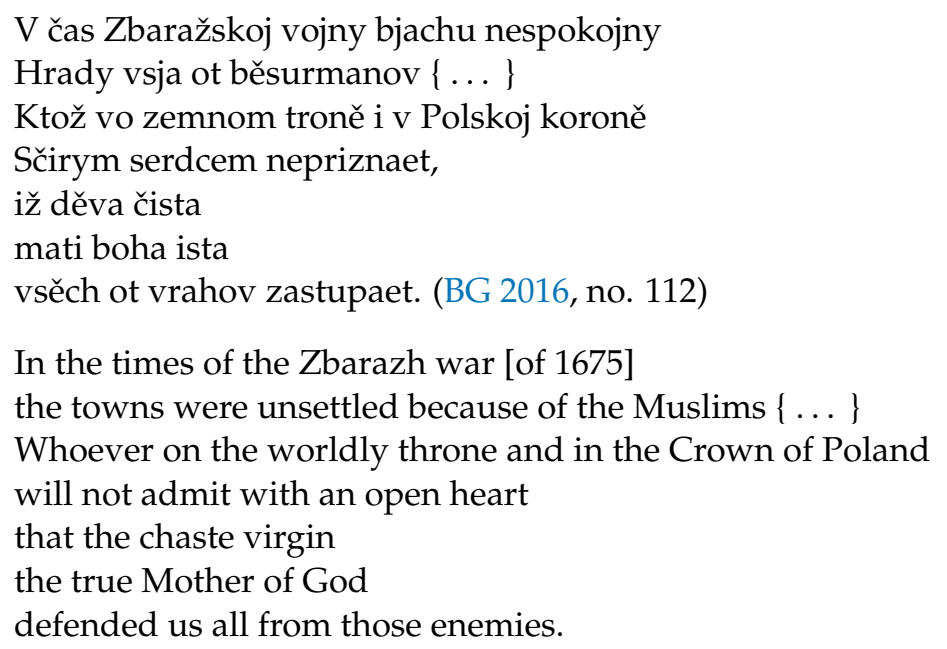

More frequently, however the relation of miraculous images to the Polish Crown is framed in an indirect manner. Many songs close with a stanza of general supplication, which is not directed specifically to the image in question, but to the Mother of God more generally. In these supplications standard formulas asking for the protection of the Polish Crown are regularly included: Błogosław Polskiey Koronie 'Bless the Polish Crown' (BG 2016, no. 122, Bilostok), Da dast v Polskoj koroně/mirno vsěm nam žiti 'Grant to everyone of us living under the Polish Crown a life in peace' (BG 2016, no. 128, Tyvriv). Some of the songs also specifically refer to the Ruthenian lands of the Polish Crown, thus establishing a prestabilized politico-geographical harmony in which the Ruthenian lands are imagined as a specific manifestation of the Polish Crown. Though the famous first line of the song in praise of the Mother of God of Pidkamin' Prečistaja děvo, mati Ruskaho kraju 'Most chaste virgin, mother of the Ruthenian land' has been repeatedly referred to as a Ruthenian or rather Ukrainian national anthem of sorts, this interpretation is proven wrong by the last stanza of this song, which indeed closes on the words Budi vsěm nam oborona/Prosit tja Polska korona jako carici 'The Polish crown asks you as her queen, to serve as a defense to everyone of us' (BG 2016, no. 134).

There is a general tendency for songs in praise of lesser known local images to use geographical references that identify the next higher administrative unit to which the place belongs-probably for practical considerations of making the place identifiable for the recipient (listener, collector) — or to drop the geographical dimension altogether. In the remarkable case of the song Preběhaem k tebě, nebesna carice in honour of the Mother of God of Povča, there is indeed no specific reference to the place and the deeds of the image at 
all. The song would look like an ordinary song of general supplication, were it not for the refrain line, which makes explicit reference to the image (Žeňuch 2006, pp. 910-11).

The texts of icon songs seem to contribute little enough to the establishment of a specific geography of grace beyond putting it in place within the common framework of sociopolitical geography. The role of these songs seems rather to lend structure to the totality of all places of grace by singling out the more deserving places from their vast mass and thus creating a hierarchy of places for particular needs against places of everyday spiritual counsel, support and consolation. One possible reason for why songs would not contribute in a direct manner through their text narratives to establishing a commonly shared Greek Catholic geography of grace might be the competitive attitude prevalent in most songs, which adhered to the golden rule of keeping silent about any other competing places of grace, even those which belonged to one's own confessional network. Even songs in praise of second to third order miraculous images would phrase their praise in a way, as if there was no other miraculous image around. Thus, the song Pomozi nam Christe Bože in praise of the Mother of God of Piddubci depicts its object of praise as a unique blessing of the heavens offered to the whole of Volhynia:

Ježeli zvažišъpričinu,

ČemъJu za matku jedinu,

Na Volynju namъNebo dalo? (BG 2016, no. 119)

If you wonder about the reason,

why the Heavens gave her

as the one and only Mother to Volhynia?

In a likewise competitive attitude the song in praise of the Mother of God of Počajiv Nyně proslavi sja Počajevska skala (BG 2016, no. 116) makes a claim of having defeated the epidemic of 1770 even at Pidhirci, Kam'janec'-Podil's'kyj and Krem'janec', which can boast well-known miraculous images of their own, thus denying their healing powers by hushing up their existence. ${ }^{57}$ There is only one icon song to break this rule of silence, ${ }^{58}$ i.e., the song Przed wieki Niebios $i$ Ziemi Królowa in praise of the image of Puhinki, which somewhat too frankly states that there are other places such as Puhinki where grace can be obtained:

Przed wieki Niebios i Ziemi Królowa,

U którey pomoc dla wszystkich gotowa,

Którey iak w wielu mieyscach tak w Puhinie,

Łaska z znacznemi dobrodzieystwy płynie. (BG 2016, no. 126)

Pre-eternal Queen of the Heavens and Earth, who offers help to everybody,

whose grace flows forth with considerable benefits in Puhinki, as in so many other places.

These lines make Puhinki look an almost random choice, which would make any pilgrim wonder why he should take the trouble to specifically go there. It is here that a quite different perspective on Uniate places of grace is granted. In these lines, places of grace are not so much seen as something exceptional and unique for one specific place. The many places alluded to may be reasonably assumed to be Basilian places, such as Puhinki. Puhinki is thus being advertised as part of a dense supply network, that provided each and every believer with conveniently accessible local grace. Individual places of grace are being framed here as part of a supply chain for graces. It is here that grace turns from something supernatural and inexplicable into an ordinary, everyday service provision. Making miracles a feature of mass consumption is liable to ultimately break down the dividing line between the sacred and the profane.

With this one notable exception, it is not so much songs in praise of specific images, but rather common Marian songs that put the networks of images into a broader perspective of 
a geography of grace. A case in point is the song Radujsja Marie, nebesna carice (Stern 2000, pp. 613-14) which establishes the idea of a chain of frontier icons defending the Polish Commonwealth against the impending Ottoman invasion. The song depicts the simultaneous weeping activities of images at three frontier sites (Terebovlja, Kam'janec'-Podil's'kyj, Chotin) as a coordinated action to fend off the aggressors (Stern 2000, p. 36). Another example, which is even more obviously meant to convey the idea that grace is ubiquitous and evenly distributed, is Čistaja děvo, nebesna carice, first attested in the Kamjanskij Bogoglasnik of 1734 (Žeňuch 2006, pp. 907-8). This song lists in apparently random succession miraculous images at Roman and Greek Catholic sanctuaries throughout Poland and Lithuania (Sokal', Częstochowa, Borek, Jaroslav, L'viv, Pidkamin', Žyrovyči, Boruny, Počajiv). By and large, it looks like icon songs focus exclusively on the local image, as if they were meant to advertise it against competing images around. Greek catholic icon songs testify to the conflicting forces of territorial competition, which on the one hand aim at establishing a common and shared Uniate geography of grace, but on the other hand evolved into an internal competition among Uniate monasteries vying for supremacy, which to some extent was liable to counteract the emergence of a collective Uniate geographical identity.

\subsection{Lop-Sided Competition}

Establishing a collective Uniate geographical identity appears to be at the heart of Basilian efforts at promoting places of grace. The ultimate aim was to create a secluded mental territory within which Greek Catholic identity would be allowed to grow without being affected by the dreaded pull of Orthodox tradition. Luckily for the Uniates, the remaining Orthodox strongholds of centuries-old Marian devotion were few, and, moreover, Orthodox monasteries and clerics did not enter into a comparable competitive activity. It looks, like Orthodox clerics took a quite different attitude to confessional competition, which appears to reflect the difference between an old confession (orthodoxy) that has lost its political backing and support and owing to its loss of cultural significance has drifted into a state of fatalistic inaction, ${ }^{59}$ and a new confession that, though it was confronted by prejudice from all sides, still had the fervor of a young and dynamic movement that was ambitiously struggling for its place (to be taken quite literally) in this world. The Orthodox-Uniate competition thus turns out to be asymmetrical, with competitive action being basically restricted to the Uniate side. ${ }^{60}$ Uniate competitive action did, however, nowhere, except perhaps in the case of the eparchy of Cholm (Jakovenko 2011-14), take the form of active encroachment upon the remaining Orthodox territory. ${ }^{61}$ The Uniate method of choice to secure one's territory was complete ignorance and erasure from the mental map of one's confessional community of anything Orthodox in order to create a hermetically closed parallel confessional world. The success of this attempt may, however, be doubted. Though, by and large, pilgrims stuck to their local or regional places of Marian devotion, many of the more renowned places seem to have been frequented by supplicants across the confessional divides. ${ }^{62}$ Whether these occasional crossings of confessional boundaries sufficiently substantiate the assumption of a common Uniate-Orthodox hierophantic macrospace (Jakovenko 2011-14) remains doubtful, though. Especially the introduction of the ultimately Roman Catholic practices of annual pilgrimages of forgiveness, as well as other forms of mass mobilization (the setting up of commissions for public hearings of witnesses, coronation procedures and celebrations, propagation of knowledge about places of grace through the proliferation in print of miracle reports, songs and print reproductions of images, etc.) were liable to erase within a relatively short time span the hereditary Orthodox map of grace and write it over with the new Greek Catholic map. ${ }^{63}$

Thus, as it comes to advertising and promoting places of grace, there is a slight confessional bias in Greek Catholic, especially Basilian efforts to get a foothold on the market of devotion and grace, which, however, never amounts to more than keeping silent about the great places of grace of Orthodoxy nearby and farther off. Only occasionally are there reports-all of them Roman Catholic in fact-that stress the superiority of Catholicism by referring to the loss of miraculous powers whenever a place of grace falls into the hands 
of Orthodoxy (e.g., Počajiv in 1839). The most outspoken case of confessional shaming is the legend of the icon of Smolensk turning against its Russian Orthodox flock on the approach of the Polish troops of Władysław IV (Kruk 2011, p. 166). For the rest, competition is largely silent and implicit in actions and choices. The ultimate cause for the mildness of competition can possibly be seen in the vividly felt unity of worshippers of miraculous images against the backdrop of Protestant and Muslim iconoclasts, which at the grass roots level resulted in a solidarity of pilgrims from all competing confessions applying to the same Marian images of supraregional fame, such as the Mothers of God at Rudki, Sokal and the Dominican monasteries at L'viv and Pidkamin', and last but not least at the Basilian monastery at Počajiv (Kruk 2011, p. 179).

\subsection{Closing the Ranks: Frontier Icons at the Antemurale Christianitatis}

The rise of Marian devotion in the 17 th-18th century has been repeatedly explained and rationalized as a reaction to the political and military insecurity of the age caused by Tatar and Ottoman Turkish raids which affected the larger part of the Ruthenian lands (Medvedyk 2015, p. 371). There can be no doubt that the insecurity of the situation helped the rise of Marian devotion, but the propagation of Marian places of grace was rather a general project of the counter-reformation all over Europe. The military confrontation offered, however, a convenient opportunity to heighten the sense of spiritual territoriality by closing the ranks against the one and only true adversary of faith and traditions alike. Miraculous images came to be imagined as part of the Christian defense system of the antemurale christianitatis. Within the Polish-Lithuanian Commonwealth the term came to be applied to the chain of frontier towns and fortresses of Chotim, Terebovlja, and most notably of Kam'janec'-Podil's'kyj (Tazbir 2017, p. 78). All of these frontier towns hosted Marian places of grace which in a way served as spiritual fortresses, thus becoming part of a war which was not only about physical conquest. It is here that the notion of sacred space is extended once again into the public and political domain, as in the case of coronation celebrations. Moreover, it is again devotional songs that make this notion of miraculous images as part of the military defense system explicit. Songs in praise of icons that can boast a victory over Ottoman troops, often take the form of a fairly detailed narrative account of the historical event, as most prominently in the case of the song Veselo spěvajte, čelom udarjajte (BG 2016, no. 112) that celebrates the defeat of the Turkish troops during the siege of Počajiv on 20 July 1675. The authors of the Bogoglasnik made a point of explicitly referring to this event in the title heading to that song:

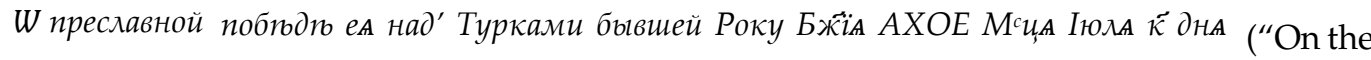
glorious victory over the Turks that took place in the year 1675, in the month of July, on the 20th day"). The song provides a vivid description of how the Ottoman troops were frightened off by a visionary appearance of the Mother of God and a legion of angels above the monastery, protecting her wards with her cloak (omofor) in imitation of its most famous model, the Blacherniotissa (Trajdos 1984, no. 128). In fact the imagery of the Pokrov miracle experienced a repopularization in the 17th-18th centuries in paintings of the period, but perhaps much more so in devotional songs in which reference to the omofor in connection with the defense from the Turks became a common and almost ubiquitous topos (Senyk 1984, pp. 268-69).

Likewise, songs in praise of less prominent images that provided their service on the immediate Ottoman frontier, tend to renarrate the military events, as in the song Prijděte vsi činy, aggelstii lici (ms. Maslov 48, fol. 116v-117r; cf. Hnatjuk 2000, pp. 193-94) that details in two stanzas the unsuccessful Ottoman attempts to blow up the fortifying walls of Terebovlja. As a matter of fact, the event by itself does not qualify as particularly miraculous. There is nothing obviously supernatural in the failed attempt of detonating an explosive charge. However, explaining the happy turn as a simple stroke of good luck would do injustice to the presence of a miraculous image nearby in a way as to almost verge on blasphemy. So, in this situation of imminent danger even the most inconspicuous event turns into a miracle and is thus made part of the larger history of divine intervention 
in favor of Christianity and the Polish Crown. The panegyrical narration of these historical events in songs turns the respective places of grace into symbolic places of collective historical memory, and thus links the sacred to the political.

It looks like Marian images formed part of the Polish defense system against Ottoman attacks. Where military means failed, local images were applied to as a last resort. Marian images are therefore likely to have been perceived as a necessary and indispensible piece of equipment of any fortified frontier town. As a matter of fact in some accounts miraculous images are in fact wielded almost like weapons. Thus, the Carmelite monastery at Berdyčiv is reported to have survived an Ottoman attack and siege owing to the courageous action of a nun who confronted the Ottoman troops on the monastery wall wielding the miraculous image as a shield to deflect the Ottoman arrows and send them back on the enemies who were thus killed in significant numbers (Chociszewski 1882, p. 263). ${ }^{64}$ The most extreme interpretation of miraculous images as weapons of defence is represented in the notion and associated practice of the war icon, which accompanies troops heading for battle. In 1673 the Mother of God of Cholm was indeed taken to the battleground in king Michał Korybut Wiśniowiecki's campaign against the Ottomans (Wereda 2018, p. 71).

Besides proving potent weapons against troops of infidels, icons seem also to be indestructible and do not give way to the brute force of attackers. Thus, at least in several cases, miraculous images are reported to have survived unscathed devastating fires layed by Tatar raiders (e.g., Nestanyč, Onyškivci). Individual attackers, however, may succeed in inflicting wounds to miraculous images, which leave scars, as in the case of the icon at Rudnja, which was whipped by heretics (Lužnyc'kyj 1984, p. 181). ${ }^{65}$ These scars, however, add to the glory of the image and are kept as a sign of suffering, not unlike the stigmata of Christ, which, as in the case of the icon at Pidhirci, resist attempts at being painted over (Baracz 1891, p. 219). ${ }^{66}$ Stories which elaborate on the invincibility and indestructability of miraculous images ought to be seen against the backdrop of profanations of religious artefacts, especially images and crosses by Ottoman invaders. Especially, the profanation of icons at Kam'janec'-Podil's'kyj upon the order of Mahomet IV in 1672 (Kruk 2011, pp. 155, 317) as well as the destruction of the church and the desecration of the icon of the Mother of God at Cholm (Kruk 2011, p. 154) must have left a traumatic imprint on the collective memory of the Ruthenian population of all denominations alike, which the legends of indestructability seem to try to make amends for by glossing the spiritual wound over by narratives of perseverance. In fact, in this particular period of crisis, rather than offering protection to the populace, miraculous images were in need of protection and care themselves. Thus, the miraculous Mother of God of Kam'janec'-Podil's'kyj was brought into safety at L'viv in 1672 by Armenian catholics, only to return to its original place in 1699 after the Ottomans were defeated for good.

In relating the sacred to the suffering in a world of historical and political upheaval, miraculous images turn not only into weapons against the enemy, but are also invoked to serve the consolidation of the political power of the state as means to preserve peace and stability: "Matko pokoiu zrządź Polskiey swobodę" ('Mother, provide for the peace of Polish freedom', BG 2016, no. 118). It is here that the individual quest for salvation and protection is transcended into a national concern, but it should also be noted, as Kruk (2011, p. 166) rightly pointed out, that the basis for collective identity formation through miraculous images is essentially local, i.e., it remains ultimately restricted to the experiential domain of the individual. It is not so much the abstract idea of a Polish nation which is at stake here, but the conditions of everyday life, of which spirituality forms an integral part in a very specific place of its own, the "world of the frontier fortresses" of Podolia, Volhynia and Galicia with their lived experience of "incessant battles against the perennial Turkish and Tatar enemy", where a particular environment of popular baroque culture emerged (Tazbir 2017, p. 73), in which miracles became enlarged into almost cosmic dimensions, that ultimately would even transcend merely national concerns. We have developed earlier the idea of the sacred engaging with physical space through images by establishing tight relations of inalienable ownership of place. This very idea is fully 
played out on the politico-social level of frontier and war icons, which, bluntly speaking, do nothing but defend their own place. Miraculous images thus become part of the overall power structure which defines itself in terms of territorial ownership.

\section{Conclusions}

The core of religious identity can reasonably be assumed to consist basically in shared beliefs about the sacred and spiritual dimensions of the world we inhabit and the shared practices associated with these beliefs. However, what if very similar beliefs are shared by competing religious communities to a degree that it becomes hard to tell one from the other and if it is, moreover, felt in one of these communities inopportune to overstress differences against common features, as was the case with Greek and Roman Catholics? The Greek Catholics of the 17th and 18th century were encumbered with a twofold identity problem. First, theirs was a confession of recent creation which had to create cohesion out of a mix of the centrifugal forces of initial indifference and traditionalist antagonism. Moreover, theirs was about to become a hybrid confession at best, with very little which it could call its own in terms of exclusive ritual or dogmatic assets. Relying on exclusively shared beliefs or age-old family allegiances was no option. Where the conceptual approach to the world of the sacred through spiritual and metaphysical ideation and dogma failed, the immediacy of physical experience of the spiritual world offered an attractive alternative to reach out to one's flock in an attempt to create communal cohesion. Following the counterreformatory Catholic model of popular mass mobilization through the objectification and commodification of the sacred in magic practices enacted and made sense of in popular texts, objects and events, Greek Catholic clerics set out to define what it means to be a Greek Catholic in terms of physical space being imbued with spirituality. Uniate spirituality manifested itself in soundscapes of songs, prayers, litanies and coronation concerts as well as in the visual landscapes of pilgrimage routes and the events and facilities offered at the places of grace as their final destinations, thus turning Uniate identity into an embodied experience. Claiming patronage and ownership over this geography of grace and designing it according to one's own hierarchical patterns, thereby embedding it into the structure of the state as a whole, proved the way for Greek Catholicism to take firm root among their envisaged community by demonstrating its sacred and secular legitimacy. The adoption of mass pilgrimages of forgiveness according to the Catholic model of indulgences as well as establishing a hierarchy of sacred places through papal coronations welded the flock to their confession, but also the confession to the Polish Crown. Territoriality became instrumental in the integration of the sacred, the political and the communal. Whenever, though, this narrowly defined territory would become subject to disintegration, Greek Catholic confessional cohesion was likely to lose its grip.

Funding: This research received no external funding.

Institutional Review Board Statement: Not applicable.

Informed Consent Statement: Not applicable.

Conflicts of Interest: The author declares no conflict of interest.

\section{Notes}

1 In this article the terms 'icon' and 'image' are used somewhat interchangeably at times. We are well aware that 'icon' is usually understood in the quite specific art historical sense of a painted sacred image of Byzantine origin and/or style, dinstinguishing it from sacred images in Western styles (in Poland mostly baroque) or even statuettes. As a matter of fact, the vast majority of miraculous images mentioned and discussed in this paper are indeed icons in the stricter sense of paintings in the Byzantine style, but some of them are not. In order to avoid confusion, we use '(miraculous) image' as a default term, employing 'icon' only sparingly in those cases where the object referred to is indeed a true Byzantine style icon. Out of stylistic considerations, we also took the liberty to use 'icon' in the more general sense of 'image' in compounds such as 'icon song' or 'frontier icon'.

2 For convenience's sake we will call this fuzzily defined terrain the Ruthenian lands with reference to the historical, ethnic, cultural and linguistic heritage of its majority population. Most miraculous Marian images on Ruthenian soil made their first appearance in the 17th-18th c. with a clear peak in the 18th c. See the lists in Ščurat (1910, pp. 10,14). The spread of miraculous images of the 
Mother of God forms, of course, part of the general rise of Marian devotion throughout Poland and the Ruthenian lands, which for the latter territories can also be gleaned from the increase of the relative share of parish churches bearing the name of the Mother of God (Jakovenko 2011-14). See also Senyk (1984). As for the Lithuanian part of the Polish-Lithuanian Commonwealth with its predominantly Ruthenian population that likeweise had to accept the Church Union, similar forms of Marian devotion can be observed, though to a notably lesser extent. We will therefore not specifically look at that region and only include it where it adds to our understanding of Marian devotion in the Ruthenian lands in general. As a matter of fact, the Ruthenian part of the Polish Crownlands (especially Galicia and Volhynia), where the Uniate Chruch came to grow particularly strong, clearly emerge as the active epicenter for the adoption and diffusion of devotional practices that follow the Western, i.e., Roman Catholic models of their time, such as the foundation and active maintenance of Marian places of grace, the establishment of annual pilgrimages, composing and collecting of devotional songs, etc. An apparent reason for this may be that in the Polish Crownlands the presence of Roman Catholic culture was much more imminent and formed part of the lived experience of the entire population, Roman and Greek Catholics alike, so that the ground for cultural confessional bricolage was better prepared here than in Lithuania.

3 The key event of iconoclastic aggression in the Polish-Lithuanian Commonwealth is evidently the 1430 Hussitic raid on Jasna Góra and the damaging and defilement of the icon of the Black Madonna. Moreover, the abortive Swedish siege of Czestochowa in 1655, which was ascribed to the intervention of the Black Madonna and led to the Mother of God being pronounced as the Queen of Poland, must have once again conjured up the iconoclastic threat (Niendorf 2010, p. 159). To these can be added minor acts of Protestant iconoclastic agression throughout Poland in the 16th century (Kruk 2011, pp. 152-54). On the whole, however, outspoken anti-Marian iconoclastic attitudes and actions were a rare exception among Polish protestants (Tazbir 1984, p. 226). For the pertinent topos of damaged and desecrated images in general cf. Kretzenbacher (1977). It must be added here that for Greek Catholics protestant iconoclasm was much less of an issue. Their territory being largely situated in the endangered frontier zone of the Ottoman empire, the role of desecrating aggressor was naturally taken over by Muslim military invaders (on which see below). On alternative explanatory accounts of the rise of Marian devotion in the 16th-17th century throughout Europe, see Jakovenko (2011-14) and Rok (2005, p. 137).

4 Levyc'ka (2017-18) identifies the 18th century bishop of L'viv, Iosif Šumljans'kyj (1700-1708) and the Uniate metropolitan bishop Atanasij Šeptyc'kyj (1729-1746) as the most active supporters of the spread of Marian worship among the Greek Catholic community through the establishment and propagation of ever new Marian places of grace. For a recent case of promoting confessional identity through pilgrimages and apparition sites among the Greek Catholics of Eastern Slovakia see Halemba (2008).

5 The political dimension of the rise of Marian devotion in the Polish-Lithuanian Commonwealth has already been noticed and commented upon by Ščurat (1910, p. 4), but we do not agree with his interpretation of Marian devotion being employed to serve the Ukrainian national cause in an attempt to fend off Polish advances into Ukrainian religious domains.

6 It is not clear whether our ethnographic approach to places of grace with its focus on interpretation and sense-making of geographical space at large would be covered by Lidov's (2006) notion of hierotopy, which is about the organisation of sacred space, to be sure, but focusses rather on aspects of immediate sensual experience especially of the ritual space as well as the art of translating mystical into sensual experience, where our approach is rather about the creation of group cohesion and corporate identity employing hierotopic features to induce interpretations of geographical space in relation to community.

7 Examples are the miraculous Marian images at Pan'kivci (Brody region, L'viv county, Galicia), Benevo (Turkiv region, L'viv county, Galicia), Lysovci (Zališčyky region, Ternopil' county, Podolia), Prjaživ (Žytomyr county), and Jatwiesk (Volkovysko area, Podlachia).

8 Lužnyc'kyj's (1984) distinction between miraculous (čudotvorni) and blessed (blahodatni) images, which seems to follow common practice, is somewhat fuzzy, so that assigning one of both labels to any one image may in some cases verge on the arbitrary. Blessed images are usually recognized only locally, and they are rather known for offering solace to the supplicant and answering prayers in a less conspicuous manner. The difference is certainly one of degrees, but it may possibly be given a sharper outline by looking at it from a more technical vantage point. Miraculous images produce eyewitness evidence that qualifies for being checked and evaluated by an episcopal committee, whereas blessed images usually rely for their fairly modest fame on the inner subjective experience of individual supplicants that as a rule will not be able to produce any kind of convincing evidence of intercession. As a matter of fact, for an image to become eligible for papal coronation it had to be officially recognized as miraculous by an episcopal committee. The recognition procedure would require a public hearing of witnesses and included also the publication of miracle reports in printed form (Levyc'ka 2017-18).

9 Though, Rožko (2002) makes an attempt at including also all images of the blahodatna type in his survey of the places of grace of Volhynia.

10 On Boruny v. Senyk (1984, p. 265).

11 The Uniate Basilian order (Ordo Sancti Basilii Magni) was founded in 1631 with the clear objective to promote the Church Union among the as yet Orthodox faithful of the Polish-Lithuanian Commonwealth. In addressing their task the Basilian Order adopted the organizational forms and patterns as well as the educational programme and policy of the Jesuit order. Like the Jesuit order, the Basilian order laid within its domain of action the foundation for a school system consisting of a dense network of monasteries and associated seminaries.

12 For the Greek Catholic Basilian order utilizing this pathway to establish a stable geography of grace of their own meant to adopt Roman Catholic ecclesiological positions on forgiveness and indulgences (Wereda 2018, pp. 69-70). 
13 Mostly on Marian feast days after the harvesting season, when the rural population was free to move. Cf. e.g., Žyrovyči, Zahoriv-September 8 (Nativity of the Blessed Virgin Mary), Cholm-September 15 (Our Lady of Sorrows). Cf. Wereda (2018, p. 75).

14 Apart from the coronated images, for which the establishment of approved pilgrimages of forgiveness was a prerequisite, these are: Povča, Novyj Sambir, Krasnyj Brod, Zarvanycja, Zahoriv, Puhinki, Bilostok, and possibly still others, which may be lacking from this list owing to the fragmentariness and incompleteness of much of the available historical information on Ruthenian places of grace.

15 For Polish examples see also Kruk (2011, p. 187), who also refers to an exceptional case of tears shed by an image being interpreted as tears of joy over the imminent victory of Władysław IV.

16 To be here understood in opposition to heterodox, i.e., to be understood as orthodox in the broad sense of any Christian confession that is conservatively oriented towards tradition and accordingly allows for the worship of images (Greek or Roman Catholic, or Russian Orthodox). The according Slavic term would be the broader pravoverrnyj rather than the specifically confessional pravoslavnyj. As a matter of fact, despite their often embittered rejection of each other, proponents of Russian Orthodoxy as well as Greek and Roman Catholicism tend to form a unified cultural block in the face of any form of belief that does not embrace miracles worked through saintly images as part of its spirituality. The fear of Muslims seems to be largely inspired by a fear of the destruction of sacred images and the concomitant loss of the sense of living in a sanctified space. The same would hold in principle for Protestants, who are indeed in some Ruthenian devotional songs portrayed as a menace to the proper faith of no lesser evil than muslims. There is one notable case of a Marian devotional song which comments on the Ottoman inroads into Podolia in the 1670s, where Muslims (commonly adressed in songs as bisurmany, aharjany or pohani) are addressed by the term 'heretic' which is usually reserved for Protestants: Jeretičeskaja ruka vsěchъnasъogortujetъ 'the hand of the heretic has a firm grip on us' (Stern 2000, pp. 44-45). An as yet more explicit identification of Muslims with Protestants, who are contrasted to all orthodox Christians (in the broad sense outlined above), is found in the following lines taken from a song in praise of the Mother of God

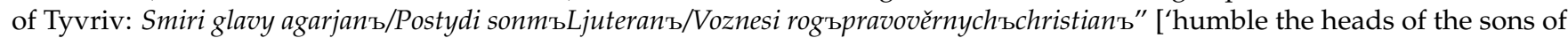
Hagar (i.e., Muslims)/Put shame on the assembly of Lutherans/Increase the power of all Christians in the right faith'] (BG 2016, no. 128). For the parallelisation of Muslim and Protestant iconoclasm specifically directed against Marian images throughout South Central Europe, cf. also Kretzenbacher (1977, pp. 94-105).

17 The following is a list of weeping images of the Ruthenian lands in the chronological order of their first miraculous manifestation: Ilins'ko-Černyhivs'ka ikona 1662, Terebovlja 1663, Klokočiv 1670, Pidhirci 1692, Povča 1696, Verchrata (Krechiv) 17th c., Vicyn end of the 17th c., Horodok beginning of the 18th c., Nastašiv after 1701, Balykyni 1711, Sambir 1727, Bucniv after 1729, Rohizno 1734, Vyšnivčyk 1742, Ternopil' 1st half of the 18th c., Tartakiv 1765, Dalešiv 1781. The rise of reports about weeping images should, however, not exclusively be accounted for in terms of the heterodox iconoclast threat. The particular emphasis on strong emotions of compassion possibly reflects the general folk baroque Catholic trend to foreground the human aspects of the relation of the Mother of God to her son, which found its most outspoken expression in the depiction of the Mother of God as fainting from pain and woe under the Cross, a topic which is also repeatedly found in Ruthenian Marian songs on the passion of Christ, as in the following lines taken from the song Vse stvorenie po umeršem paně: Mati Christova pod krestom stojala/Z žalju tjažkago srodze omlěvala ['The Mother of Christ stood under the Cross, she fainted severely from her heavy woe'] (Stern 2000, pp. 155-56, 533). The particular emphasis on emotions of compassion is ultimately grounded in Franciscan mysticism and its conceptualisation of the Mother of God as mater dolorosa being pierced by the sword of pain (gladius doloris). Later on, similar notions were elaborated upon by the prominent theologist of Russian orthodoxy, Gregory Camblak in his Homily on the Dormition of the Mother of God (Trajdos 1984, p. 134). Among the Greek Catholic community the cult of the Mater dolorosa spread, however, via Western pietà iconography from the mid 17th century onwards (Senyk 1984, p. 273).

18 See Kruk (2011, p. 174) on Žyrovyči and parallel cases in Poland.

19 For the origins and other examples of this topos see Kruk (2011, p. 173).

20 Vasil' Surožskij stresses in his treatise O jedinoj istinnoj prawoslawnoj věrě (Ostrog 1588), accordingly, that the miraculous powers of icons derive from their being created through the assistance of God (RIB 7 1882, col. 929-30).

21 It goes without saying that reports and legends about miraculous images reflect the perspective and interests of its authors. Thus, wherever the author of a legend is likely to be a Basilian, as in the case of Pidhirci, movement to a Basilian sanctuary is unlikely to be reported as having caused averse reactions by the image being moved.

22 This report, in fact, reflects a very common topos of long-standing, which in the Polish-Lithuanian Commonwealth was strongly reinforced by a similar legend about the Black Madonna of Częstochowa (Kruk 2011, pp. 180-83).

23 Only exceptionally and under very specific circumstances will miraculous images swap loyalties, as in the case of the Mother of God of Smolensk, which is reported by a Polish chronicler to have turned on their own Orthodox wards when being attacked by the troops of the son of the Polish king Władysław IV (Kruk 2011, p. 166). Similarly, an indeterminate number of smaller 'Muscovite' icons seem to have been brought to Poland by the same invading troops during the times of trouble without losing their miraculous powers (Kruk 2011, p. 62). Thus, even the strict local loyalty of images seems to have its limits where issues of the right confession are concerned, as when an Orthodox surrounding can be exchanged for a Catholic one. Here, again, the confessional background of the report is crucial.

24 A key contemporary text which elaborates from an Orthodox perspective on the relationship between icons and the sacred, is Surožskij's O edinoj istinnoj pravoslavnoj věrě (1588)—especially the closing chapter on images and icons (O obrazochъi ikonachъ). 
Surožskij admits on the one hand that icons and other holy objects are created by men out of dead matter, but that God chooses to dwell in them and engages through them with this world. Thus, the icon is for Surožskij at the same time representational of the sacred as well as imbued by the sacred. It holds the middle ground between conceptual sign (col. 921 and col. 929-30) and material medium cum chosen place for God to be in this world (col. 921, 923-24, 926-27). According to Orthodox notions, miracles are not worked immediately through icons, but through the grace of God who thus reacts to icons being applied to for help (Levyc'ka 2017-18). Where according to this officious Orthodox conceptualization icons are not to be identified with the sacred and cannot therefore acquire personal features, under the influence of Catholicism this boundary becomes increasingly porous through phenomena such as weeping and bleeding images, which strongly suggest a true animacy and personhood for images (Niedźwiedź 2005, p. 95; Kruk 2011, pp. 184-85). See also Kretzenbacher (1977, pp. 7-8) who refers to this as empsychosis and ensomatosis. It is through weeping that communication between the faithful and the sacred turns from a one way road of mere supplication into a mutual, though not truely dialogic exchange of personal perspectives and intentions by means of interpretable communicative behaviour. When in her attempt to deny this material aspect of Marian worship Oleksandra Hnatjuk concludes that in the praise of icons “нівелюєтсься не лише світський час, але й простір" (Hnatjuk 1994, p. 118) she falls victim to a disembodied idealism that is not borne out by the facts, as was already remarked by Medvedyk (1999, p. 76). See also Niendorf (2010, pp. 158-59).

26 Copies of the Black Madonna of Czestochowa that had been rubbed against the original were held in highest esteem, and some of them became famous destinations for pilgrimages themselves, such as the icon of Mydlów (1748) and Solec (1763) (Kruk 2011, p. 161). See also Rožko (2002, p. 86) for the miraculous icon of Počajiv, copies of which, that were made miraculous in the way described, were disseminated over Ukraine and Russia.

27 Evidence for the Ruthenian lands is hard to come by Chociszewski (1882, pp. 263-64) mentions an anecdote of Juliusz Słowacki's being sent by his mother a print repoduction of the Mother of God of Berdyčiv, which served him as support in many hopeless situations. Print reproductions (wood cuts and copper etchings) were made of the miraculous images at Pidkamin', Sokal', Berdyčiv, Počajiv, Hošiv and Zarvanycja (Levyc'ka 2017-18; Wereda 2018, p. 76). It is, however, not known whether these reproductions were being sanctified by rubbing them against their originals. It can, however, be surmised that this practice which was quite commonly applied to small print reproductions of the Black Madonna of Częstochowa (Kruk 2011, p. 161) was also known and accordingly employed among the Greek Catholics of Ruthenia. It seems, however, that a more common practice at Częstochowa consisted in rubbing kerchiefs and rozaries against the image (Tazbir 1984, p. 227). See also Kürzeder (2005, pp. 52-54) for a detailed discussion of similar practices in the Southern German-speaking lands.

28 This point is neatly illustrated in Saltykov-Ščedrins novel Gospoda Golovlevy, where the major protagonist Arina Petrovna, head of the Golovlev family who is obsessively bent on the acquisition of material riches, orders a service of supplication (moleben) to the famous miraculous icon at the Iviron monastery on Mount Athos to help her purchase by auction a village of 1000 souls (Saltykov-Ščedrin 1979, p. 39). The Iverskaja bogomati was indeed one of the most popular icons among all the Eastern Slavs and had many replicas at various places throughout the Ruthenian lands (Lužnyc'kyj 1984, p. 167). Citing this biting satire is not meant to suggest that Arina Petrovna's might reflect a common attitude. It serves only to highlight the inherent tendencies in supplication and its desanctifying potentials. By the by, her application to a far away icon of world wide fame instead of to a local icon nearby tells a lot about the competitive hierarchy that holds between places of grace which translates into the branding of efficacy and the emergence of a system of exchange values on the market of miracles.

29 As in the case of the resurrection of a child on 15 August 1710 (Przesławna gora poczaiowska Dawnością Cudow Przenayczystszey Bogarodzicy Panny od cudownego Jey Obrazu wynikajacych [1787] 1801).

30 Several of the reports on the early healing miracles at Pidkamin' describe this procedure with the prefabricated formula "ofiarowat się do Obrázu Naświętszey Pánny mieyscá Podkamienieckiego" ['he offered to the Image of the most holy Lady at Pidkamin”]. When the healing was granted and health fully recovered, the supplicant would set out to Pidkamin' in person ("y nieco po chrobie wypocząwszy reddendi voti causa był w Podkamieniu", Okolski 1648, fol. 27v).

31 A desire for the physical representation of miraculous powers and their visible manifestation can also be gleaned from the common practice of adorning miraculous images with gold or silver frames, studding them with precious stones, and the like, as well as hanging votive tablets around them. These practices were common all over Catholic Europe and the Roman and Greek Catholics of the Polish-Lithuanian Commonwealth did definitely not lag behind this common trend. For Roman Catholic Poland see Kruk (2011, pp. 214-17, 245-58). Among the Greek Catholic places of grace Počajiv and Pidhirci stand out for their wealth and abundance of the votive tablets they were adorned with. This basically Catholic practice became also quite popular among the remaining Orthodox communities (Senyk 1984, pp. 263-64). It goes without saying that the number of votive tablets accumulated served also as visible evidence of the efficacy of the image in question and would raise its esteem and value among pilgrims.

32 On coronations of miraculous icons as a key hierotopic element of Greek Catholic efforts to stage the sacred foundations of state and society, see Levyc'ka (2017-18) and Wereda (2018). The coronation of miraculous images came to be a common practice under Pope Urban III from 1630 onwards. It was in the beginning restricted to Italy, especially Rome, and spread abroad with the coronation of the Black Madonna of Częstochowa on 8 September 1717. Only those miraculous images that could be shown to be ancient, which preferentially implied a Greek (Byzantine) origin, were eligible for coronation. Cf. Kruk (2011, pp. 241-45) and Levyc'ka (2017-18). Among the images that constitute the Greek Catholic geography of grace, the following were coronated in the 18th century: Žyrovyči (Basilian, 1726/1730), Pidkamin' (Dominican, 15 VIII 1727), Bucniv (Basilian, 1738), L'viv (Dominican, 1751), Berdyčiv (Carmelite, 16 VII 1753), Cholm (Basilian, 1765), Počajiv (Basilian, 8 IX 1773). The inclusion of the Roman 
Catholic sites Pidkamin' and Berdyčiv into the Greek Catholic geography of grace can be additionally gleaned from the fact that the coronation celebrations at both sites were designed as ecumenical (including Roman, Greek and Armenian Catholics) (Levyc'ka 2017-18).

33 We are not suggesting here, though, that the 1656 Lwów Oath (śluby Jana Kazimierza), when the Polish king Jan Kazimierz declared the Mother of God Queen of Poland, served as a direct source of inspiration for the coronation procedures of the 18th century, making it thus a prerequisite for this later practice. Although the metaphorical link is quite obvious, a direct causal link between the Oath and later coronations would still have to be made evident by further research into the matter. There is, by the way, little direct evidence that the idea of the Mother of God as the Queen of Poland was actually extended to the Lithuanian part of the Commonwealth. See Niendorf (2010, p. 158), who cites at least one contemporary source in support of this assumption. An impressive example of this kind of commemorative volume is Trześniewski (1767).

35 The ambitions of Počajiv were not restricted to the immediate regional level, but aspired to catch up with the famous Kievan Cave monastery, with which it came to share the honorary title of lavra (Trajdos 1984, p. 134).

36 See Nastalska-Wiśnicka (2015) for an overview of text genres associated with Marian sanctuaries in 16th-18th century Poland.

37 For the role of music and singing in creating a soundscape of sanctity and spirituality, see Fisher (2014), and with particular reference to the Greek Catholic church Lorens (2019).

38 Especially the famous song in praise of the Mother of God at Pidkamin' Prečistaja děvo, mati ruskago kraju has been repeatedly used as a model for songs in praise of images at other places (Počajiv, Tyvriv, Chotyn). Likewise the songs in praise of the miraculous image of Vicyn Děvo mati preblagaja, tys' carice nebesnaja (>Počajiv, Kiev, Povča) and the miraculous image of Sambir Divna tvoja tajna, čistaja, javisja (>Bar, Povča) were appropriated and remodeled for the sake of other places of grace.

39 In fact, the majority of icon songs in the Bogoglasnik of Počajiv (BG 2016, nos. 110-11, 114-25) are identified as being authored by Basilian monks (творение инока чинуC. Василїа B. or Dzieło zakonnika Bazyliana). In some cases explicit reference to the Basilian order within the song points to a Basilian authorship (e.g., in the 5th stanza of the song in praise of the icon of Jatwiesk, cf. Stern 2000, p. 648). The Polish song Drogi klejnocie naroda ruskiego in praise of the Mother of God of Vicyn was also authored by a Basilian (Al'mes 2018, p. 272).

40 Incipit 'Poběditel'naja vsěm kievskaja strana', attested in ms. ASP 233 and the Kam'jans'kyj BG of 1734 (cf. Medvedyk 1999, pp. 72-73). 41 Being based on Stern (2000), Žeňuch (2006), Medvedyk (2015) and (BG 2016).

42 Transcarpathia: (1) Klokočev-(2) Krasnyj Brod-(3) Povča. Ciscarpathia: Kuty (4). Galicia: (5) Hošiv-(6) Kam'jankaStrumylova-(7) Pan'kivci-(8) Pidhirci-(9) Pidkamin'—(10) (Novyj) Sambir-(11) Ulaškivci-(12) Zarvanycja-(13) Benevo(14) Tartakiv. Volhynia: (15) Krystynopil'—(16) Piddubci—(17) Počajiv—(18) Zymne—(19) Radechiv. Podolia: (20) Bucniv—(21) Jarka-(22) Kam'janec'-Podil's'kyj-(23) Nastašiv-(24) Ternopil'-(25) Tyvriv-(26) Lysovci. Žytomyr: (27) Berdyčiv-(28) Prjaživ-(29) Tryhory. Černihiv: (30) Lin'kiv—(31) Tupyčiv. Bukovina: (32) Chotyn-(33) Terebovlja. Podlachia: (34) Dalešiv(35) Jatwiesk-(36) Žyrovyči. Mohyliv: (37) Bar. Peremyšlja: (38) Peremyšlja-(39) Vicyn.

43 On the face of it, the language choice would be suggestive of an ongoing language shift from Ruthenian to Polish among the local population. However, none of the places in question is likely to have undergone a majority shift to Polish. Galicia: (1) Bilostok-(2) Bil'šivci. Volhynia: (3) Puhinki-(4) Zahoriv. Podolia: (5) Krem'janec'_-(6) Zahajci. Polissia: (7) Jurewicze. Language choice might perhaps rather reflect the linguistic preferences within the ranks of the Basilian order, which has long been known for increasing Polonizing tendencies. There are several places (Počajiv, Pidkamin' and Zarvanycja) for which songs in both languages have been composed. Given the supraregional fame of these places of grace, bilingual usage can best be explained as an effort to cater for the needs of pilgrims from all over the Commonwealth. We are quite confident that our count comes quite close to the actual number of images for which songs have ever been composed, but an extended search that would include a larger number of the countless manuscript collections of Ruthenian devotional songs might reveal yet a few more items of less widely circulated songs in praise of other miraculous images.

44 For Počajiv an impressive number of 11 different songs could be identified: (1) Witay cudowna matko w Poczaiowie, (2) K tebě, božija mati, priběgaem, Obremenenni grěchami vzyvaem, (3) Mnogimi usty glasi ispusti, (4) Veselo spěvajte, vsi čelom udarjajte pred Matkoju Christovoju (cesarevoju), (5) Vselennyja vsja strany, zemljane, (6) Děvo mati preblagaja, Tys' carice nebesnaja, (7) Prečistaja děvo mati v Volynskom kraju, (8) Nyně proslavitsja Počaevska skala, (9) Zlatozarnye zori počavskie, (10) Izyjděte dvory so sobory, (11) Pasli pastyri ovci na gorě.

45 Basilian places of grace honoured in songs are: Bar (former Dominican monastery), Bilostok, Bucniv, Dalešiv, Hošiv, Jatwiesk, Krasnyj Brod, Krem'janec', Krystynopil', Piddubci, Pidhirci, Počajiv, Puhinki, Pušni, Tryhory, Ulaškivci, Vicyn, Zahajci, Zahoriv, Zarvanycja, Zymne-Dominican places: Pidkamin', Tyvriv—Carmelite places: Berdyčiv—Jesuit places: Nastašiv.

46 In a similar vein, Ščurat (1908a, p. 48) argues that the icon songs in praise of diverse Basilian Marian places of grace were commissioned for the edition of the Bogoglasnik. See also Medvedyk (2006, pp. 26-27).

47 This seems to be true of the song in praise of the Mother of God at the Dominican monastery at L'viv Izyjděte ď̌čery ierusalimskija (ms. Maslov 54, Hnatjuk 2000, pp. 197-98), which mentions the coronation as an ongoing event happening simultaneously to the singing of the song (dnes' ukoronovana). Cf. also the small brochure for the coronation of the icon of Počajiv 1773 (Medvedyk $2000 a$ ), which contains a number of songs in praise of the icon that are attested in this very brochure for the first time and may therefore be assumed to have been specifically composed for the compilation of the brochure, i.e., for the coronation feast itself.

Such as the Suprasl' collection F 19-233 of the 1730s-40s; v. Stern (2000). 
The earliest booklet of this kind appeared in 1734 in honour of the icon of Rohizno, which in that very same year had manifested her miraculous powers (Medvedyk 1999, p. 76; Medvedyk 2001, p. 92). The most prominent of this kind of occasional print brochures is certainly the Gora počajevskaja stopoju i obrazom čudotvornym Presvjatoj Děvy Bogorodicy počtenna published in 1742, and then again in 1755, 1772 and 1793. Around 1772-73 appeared a small print edition of songs and prayers on the occasion of the coronation of that same icon (for an edition see Medvedyk 2000a). A polish language volume in praise of the same icon, that contained one Ruthenian icon song, was published in 1765, and again in 1778 (Kasparowicz 1765). A small print edition of songs in praise of the miraculous icon at the Dominican monastery at L'viv was published on the occasion of the icon's coronation in 1751 (Pieśni o Nayświętszey Maryi Pannie w Cudotwornym Obrazie Lwowskim; cf. Medvedyk 2006, pp. 120-21). The commemorative volume Obrona Polskiey korony ot granic Ukrainskich (1760) in praise of the miraculous image of Berdyčiv contains one Ruthenian icon song, which, however, with one exception never found its way into manuscript song collections (Medvedyk 2006, pp. 131-32). This volume was later on significantly enlarged by Trześniewski (1767).

50 For instance, the selection of Maslov 45 (cf. Medvedyk 2000b) offers a representative choice of all major Ruthenian regions: Pidkamin' (Galicia), Počajiv (Volhynia), Vicyn (Peremyšlja), Lin'kiv (Černihivščyna), Bzov and Rudnja (Kyjivščyna). In contrast to this, the Ivanovce song manuscript (cf. Javorskij 1934, pp. 111-27) has a more narrowly defined regional profile, with a clear focus on Galicia: Pidkamin', Sambir, Zarvanycja, Kam'janka-Strumylova (all Galicia), Počajiv (Volhynia), Bar (Podolia), Povča (Transcarpathia).

51 An analysis of 86 manuscript collections of Ruthenian devotional songs from the 18th-19th c. yielded the following list for Marian sites being included in more than 5 manuscripts: Pidkamin' (44 mss.), Počajiv (33), Sambir (29), Bar (24), Kam'janka-Strumylova (20), Zarvanycja (13), Povča (10), Vicyn (9), Lin'kiv (8).

52 Žyrovyči in 1727 and Cholm in 1765.

53 On collectors of Ruthenian devotional songs and the emergence of a popular collectors' culture see Stern (2021).

54 A fine example of this is the song in praise of the Mother of God at Počajiv Veselo spěvajte, čelom udarjajte (BG 2016, no. 112) that offers a doxological narrative in verse of the Ottoman siege of the larger region in 1675. In the lines $V_{\mathrm{b}}$ časъZbaražskoj vojny bjachu nespokojny/Grady vsja ot běsurmanovъ the idea of the Ottoman frontier as a chain of towns forming the Antemurale Christianitatis is neatly evoked.

55 The song in praise of the Mother of God at Počajiv Nyně proslavi sja Počajevska skala (BG 2016, no. 116) capitalizes on the healing powers of the image by reporting on the regional epidemic (mor) of 1770 . It lists stanza by stanza the places that were afflicted and granted deliverance from the plague by the icon of Počajiv. By listing these places the author seems to rely on a common cognizance shared by his addressees of which localities are most intimately linked to Počajiv as its spiritual point of reference and thus constitute a geography of grace, which the author construes as a space of shared embodied experience, in contrast to the largely disembodied administrative and political conceptions of space that predominate in other icon songs.

56 Tyvriv (BG 2016, no. 128: Soglasno krikněte, christiane sja sniděte, so liky, timpany, ot vseja strany 'Call out in harmony, join in, Christians from all countries, with the choirs and the tympana'), Novyj Sambir (Ščurat 1908b, p. 183: Dneś wo wsia strany uże razsianny/Ko tebi Maty! od siudu wotaiem 'Today all countries which are spread over the world call to you from all directions'). This Počajevan partisanship is countered by two songs having been authored by one Andrzej Jakubiński in october 1770, who gives credit to the miraculous image of Sambir for having ultimately saved the region from the same epidemic (Ščurat 1908b, pp. 181-85).

58 The rule of silence, which we saw being applied internally to competing places of grace of one's own confessional domain, was with even greater naturalness applied to the great competitor in the field, the Orthodox church which in the places, where it still remained, could often boast miraculous images of centuries-old tradition. Greek Catholic songs would attempt to obliterate these from the consciousness of the Greek Catholic pilgrims. In the case of Zymne the Basilian monks actively promoted the cult of their recently introduced miraculous image by means of an icon song (BG 2016, no. 125) in order to outshine its much older and more dignified counterpart at the nearby Orthodox monastery (Lužnyc'kyj 1984, p. 167). By perfidiously ignoring the existence of the latter it seems as if the Basilian monks hoped for their own new miraculous image to profit from the fame of the latter through the confusion of both by the unsuspecting pilgrim.

59 See Trajdos' (1984, p. 131) assessment of Marian worship among the Orthodox faithful ever since the Polish-Lithuanian Union of 1386 and the subsequent catholization of almost the entire political class of the Grand Duchy of Lithuania. Where up to this point the Ruthenian lands partook in the expanding common East-Slavic cult of palladium icons as symbols of the union of the sacred and the political power, which typically were located at the centers of political power (Kiev, Černihiv, Smolensk, Wolodymir Volyns'kyj, Luc'k, etc.), the loss of the political power of Orthodoxy brought the establishment of new Marian places of grace to a sudden halt. The appearance of the Greek Catholic Basilians with their strong emphasis on Marian devotion in the 17th and 18th century could thus capitalize on the general decline of Orthodox culture by filling in the gap left by centuries of lethargy to set up an entirely remodeled geography of grace for their flock, which focussed more on the as yet Ruthenian speaking countryside than on the heavily polonized and catholicized towns and cities.

60 If we apply the imagery of the religious marketplace, as did Mahieu and Naumescu (2008, pp. 14-16) with respect to the present situation of the Uniate Church, to the 17th-18th centuries, there was in fact not much of a market place offering free choices to the individual believer. Yet, the steps taken by the Uniates in promoting Marian devotion clearly bespeak a strategy applicable in a situation of open competition. Uniate competitive behabviour does, in fact, not directly address a competitor, but is directed at the believers' competing loyalties that oscillate between whole-heartedly accepting the legally imposed Church Union and sticking to the tradition of defeated Orthodoxy. 
61 Jakovenko (2011-14) aptly calls this 'territorial correctness'.

62 See among others the often repeated remark in Baracz (1891) that the image being described is being visited by all confessions alike. See also Jakovenko (2011-14).

63 Writing over the traditional Orthodox map of grace smacks of cultural domination, and, as a matter of fact, Uniates, in particular Basilian monks in their efforts to follow the Jesuit model of confessional cultural re-education significantly contributed to an active policy of Western, i.e., Catholic reorganization and domination of the Orthodox cultural sphere. Yet, Uniate action lacked the open assertiveness of their Roman Catholic models so much so that the notion of dominance does not impose itself rightaway on the observer. It seems that, shunning any form of open confrontation on the discourse level of e.g., confessional polemics, Uniates were forced to resort to positive action, in which they took great care not to incur the accusation of encroachment (v. above on the Uniate policy of 'territorial correctness'). This restrained self-assertion may be taken as a symptomatic feature of the Uniates' role as a "bridge between two cultural spheres" (Mahieu and Naumescu 2008, p. 2).

64 This again is a variation of the topos of the Blacherniotissa. The Marian visions reported for Počajiv (1675) and Terebovlja (1673) reflect in a more direct manner its Constantinopolitan prototype.

65 According to the folk ideological notion of ensomatosis (Kretzenbacher 1977, p. 7), wounds inflicted to miraculous images are true physical wounds, which ought to be bleeding, accordingly.

66 The ultimate model for this specific topos of the injured image which resists attempts at repair, is the Black Madonna of Czestochowa. The interpretation as stigmata that testify to the act of redemption through sacrifice and suffering can be gleaned from Rotter (1756): “To dziw u wszystkich sprawuje Przecudowna Matka, że ran zostawionych na Twojej twarzy, żaden sposób ludzki zgładzić nie może. Darmo do tego końca i największej doskonałości malarze w farbach moczą. Ale domyślam się, dlatego chcesz je mieć niezgładzone $\{\ldots\}$, abyś dała znak jawny niewygasłej ku nam miłości Twojej, dla której tak ciężkie przepuściłaś sobie rany" (This miracle professed the miraculous Mother in the presence of all, that the wounds inflicted on Your face, cannot be removed by any human art. To this end even the most artful painters apply their colours in vain. But I surmise that it is for this reason that you refuse to have your wounds removed $\{\ldots\}$ that you might give a visible sign of your inextinguishable love to us, for which you suffered to have these heavy wounds inflicted upon you.'). See also Kretzenbacher (1977, pp. 50-52).

\section{References}

Al'mes, Ivan. 2018. «Drogi klejnocie naroda ruskiego»: Духовна піснясерединиХVIII століття на честьікони божої матері Віцинського Василіянського монастиря. Калофонія 2018: 265-77.

Barącz, Sadok. 1891. Cudowne obrazy Matki najświętszej w Polsce. Lwów: Nakładem autora.

BG. 2016. Bogoglasnik-Pěsni blagogověnyja (1790/1791). Eine Sammlung geistlicher Lieder aus der Ukraine. Edited by Hans Rothe and Jurij Medvedyk. 2 vols, Cologne, Weimar and Vienna: Böhlau.

Chociszewski, J. 1882. Pielgrzymka do ważniejszych miejsc w ziemiach polskich wsławionych cudownemi obrazami N. Maryi Panny. Poznań: G. Jalkowski w Grudziądzu.

Eliade, Mircea. 1957. Das Heilige und das Profane. Vom Wesen des Religiösen. Reinbek bei Hamburg: Rowohlt.

EMKC. n.d. Epistolae metropolitarum Kioviensium catholicorum (Raphaelis Korsak, Antonii Sielava, Gabrielis Kolenda, 1637-1674). Edited by Athanasius G. Welykyj OSBM. Rome: PP. Basiliani.

Fedotov, George P. 1946. The Russian Religious Mind. Kievan Christianity, the Tenth to the Thirteenth Centuries. New York, Evanston and London: Harper \& Row.

Fisher, Alexander J. 2014. Music, Piety, and Propaganda: The Soundscapes of Counter-Reformation Bavaria. Oxford: OUP.

Fridrich, Alojzy. 1904. Historye cudownych obrazów najświętszej Maryi Panny w Polsce. Kraków: Wydawnictwo Tow. Jez.

Gliczner, Erazm. 1598. Appellatia ktora sie popiera z znowu wywodźi obrona dołozna Confederatiey krolestwa polskiego, z okażaniem pewnym, ze euangelicy Auspurskiey confessiey, tu w Polszcze, w Litwie, w Prusiech y wszędzie w państwie korony Polskiey, w miástách koronnych, stołecznych, i innych \{... \}. Królewiec: Dziedzicy Georga Osterbergera.

Halemba, Agnieszka. 2008. Greek Catholics of Zemplin: Dilemmas of Contemporary Identity Politics. In Churches In-between. Greek Catholic Churches in Postsocialist Europe. Edited by S. Mahieu and V. Naumescu. Berlin: LIT Verlag, pp. 299-318.

Harasiewicz, Michael. 1862. Annales Ecclesiae Ruthenae. Leopolis: Institutum Ruthenum Stauropegianum.

Hnatjuk, Oleksandra. 1994. Українська духовна барокова пісня. Warsaw-Kiev: Pereval.

Hnatjuk, Oleksandra. 2000. Барокові духовні пісні зрукописних спів аниківXVIII ст. Лемківщини. L'viv: Misioner.

Hruševs'kyj, Mychajlo. 1897. Сьпіванник з початку XVIII в. ЗапискиНаукового Товариства імени Шевченка 15 \& 17: 1-98.

Hymes, Dell. 1972. Models of Interaction of Language and Social Life. In Directions in Sociolinguistics: Ethnography of Communication. Edited by J. J. Gumperz and D. Hymes. New York: Holt, Rinehart \& Winston, pp. 35-71.

Jakovenko, Natal'ja. 2011-14. «Битва за душі»: Конкуренція богородичних чуд міжуніятами та православнимиу 17 ст. (відТеодозія Боровика до Йоаникія Галятовського). Harvard Ukrainian Studies 32-33: 807-25.

Javorskij, Julian A. 1934. Материалы для историистаринной песенной литературы в подкарпатскойРуси. Prague: Orbis.

Kasparowicz, Gabryel Andrzej. 1765. Zrodło ogrodów, studnia wod żywych ktore płyna impetem z Libanu [ ... ] to iest Officium albo godzinki Nayś. Maryi Pannie na Górze iasney Poczaiowskiey [ . . . ]. L’viv: Drukarnia Collegii.

Kretzenbacher, Leopold. 1977. Das verletzte Kultbild. Voraussetzungen, Zeitschichten und Aussagewandel eines abendländischen Legendentypus. München: Bayerische Akademie der Wissenschaften.

Kruk, Mirosław Piotr. 2011. Ikony-obrazy w światyniach rzymsko-katolickich dawnej Rzeczypospolitej. Kraków: Collegium Columbinum. 
Kürzeder, Christoph. 2005. Als die Dinge heilig waren. Gelebte Frömmigkeit im Zeitalter des Barock. Regensburg: Schnell \& Steiner.

Levyc'ka, Mar'jana. 2017-18. Короновані ікони Богородиці вукраїнськійунійній традиціїXVIII-XIX ст. (істориогра үіяі зразки). Карпати: людина, етнос, цивілізація 7-8: 270-84.

Lidov, Aleksey. 2006. Иеротопия. Создание сакральных пространств как вид творчества и предмет исторического исследования. In Hierotopy. Creation of Sacred Spaces in Byzantium and Medieval Russia. Edited by A. Lidov. Moscow: Progress-Tradition, pp. 9-31.

Lorens, Beata. 2019. Muzyka w działalności duszpasterskiej Bazylianów w Rzeczypospolitej w XVIII wieku. Muzyka 64: 49-69. [CrossRef]

Lužnyc'kyj, Hryhor. 1984. Словник чудотворних богородичних ікон України. In Intrepido Pastori. Науковий збірник на честь блаженнійшого патріярха Йосича в40-ліття вступлення на Галицький престіл, 1.11.1944. Rome: Universitas Catholica Ucrainorum S. Clementis Papae, pp. 153-88.

Mahieu, Stéphanie, and Vlad Naumescu. 2008. Introduction: Churches In-between. In Churches In-Between. Greek Catholic Churches in Postsocialist Europe. Edited by S. Mahieu and V. Naumescu. Berlin: LIT Verlag, pp. 1-32.

Medvedyk, Jurij Jevhenovyč. 1999. Українські богородичні канти другої половиниXVII-XVIII ст. Народна творчість та етнограчія 269: 71-80.

Medvedyk, Jurij Jevhenovyč. 2000а. Пісні до Почаївської богородиці. L'viv: Misioner.

Medvedyk, Jurij Jevhenovyč. 2000b. Нижньо-тварожськийспіваниксередини30-тих роківXVIII ст.: його місце вукраїнській духовнокантовій культурі та рукописній традиції жанру. In Slovensko-rusinsko-ukrajinské vzt'ahy od obrodenia po súčasnost'. Edited by Ján Dorul'a. Bratislava: Slavistický kabinet SAV, pp. 350-70.

Medvedyk, Jurij Jevhenovyč. 2001. Духовні канти в честь чудотворних храмових святиньГаличини. Українське музикознавство 30: $90-103$.

Medvedyk, Jurij Jevhenovyč. 2006. Українська духовна пісняXVII-XVIII століть. L'viv: Ukrajins'kyj katolyc'kyj universytet.

Medvedyk, Jurij Jevhenovyč. 2015. Іконославильні пісні Полісся, Поділля, Волині та Галичини вспівочій культурі Мукачівської єпархіїXVIII-XIX ст. In Ad fontes: Зісторіїукраїнської музикиXVII-початку XX ст. L'viv: KNU imeni Ivana Franka, pp. 371-90.

Nastalska-Wiśnicka, Joanna. 2015. Staropolskie piśmiennictwo sanktuaryjne jako źródło do badań nad kultem Maryjnym na ziemiach Rzeczypospolitej. Textus et Studia 4: 47-70.

Niedźwiedź, Anna. 2005. Obraz i postać. Znaczenia wizerunku Matki Boskiej Częstochowskiej. Kraków: Uniwersytet Jagielloński.

Niendorf, Mathias. 2010. Das Großfürstentum Litauen. Wiesbaden: Harrassowitz.

Okolski, Szymon. 1648. Góra święta Najśw. Panny Różańca św. w Łuckiem biskupstwie na Wołyniu nad miastem Podkamień, przedziwnemi cudami, y stopkami Panieńskiemi, Dekretem Pasterskiem y wielu pielgrzymowaniem wsławiona. Kraków: Łukasz Kupisz.

Pap, Stefan. 1971. Духовна пісня на Закарпатті. Analecta Ordinis S. Basilii Magni 7: 114-42.

Pruszcz, Piotr Hiacynt. 1662. Morze Łaski Bożej, które Pan Bog w Koronie Polskiey po różnych mieyscách, przy Obrázách Chrystusa Páná, y Matki iego Przenayświętszey ná Sercá ludzi pobożnych, y w potrzebách rátunku żądaiacych, z głębokości miłosierdzia swego, nieprzebránego, co dzień obficie Wylewa. Kraków: Drukarnia dźiedźików Stanisława Lenczewskiego Bertut.

Przesławna gora poczaiowska Dawnością Cudow Przenayczystszey Bogarodzicy Panny od cudownego Jey Obrazu wynikających. 1801. Poczajów: Drukarnia WW. OO. Bazylianów. First published 1787.

RIB 7. 1882. Vasil' Surožskij, О единой истинной православной върғ и о святой соборной апостолской церкви, откуда начало приняла, и како повсюду распростреся. Сочиненіе Острожскаго священника Василїя 1588 года. “О образохъ рекше о инконахъ". Русская историческал библиотека, издаваемая археограчическою комииссиею 7: 918-38.

Rok, Bogdan. 2005. Sanktuaria Maryjne ziem ruskich w kulturze Rzeczypospolitej XVIII wieku. In Czasy nowożytne. Studia poświęcone pamięci prof. Władysława Eugeniusza Czaplińskiego w 100 rocznicę urodzin. Wrocław: Instytut historyczny, Uniwersytet Wrocławski, pp. 137-47.

Rotter, o. Ksawery. 1756. Ucieczka grzeszników albo nabożny zasmuconych recurs do dzielney cudami Częstochowskiey Matki. Częstochowa: Drukarnia Jasney gory Częstochowskiey.

Rožko, Volodymyr. 2002. Чудотворні ікониВолині і Полісся. Luc'k: Media.

Saltykov-Ščedrin, M. Е. 1979. Господа Головлевы. Сказки. Moscow: Chudožestvennaja literatura.

Senyk, Sophia. 1984. Marian cult in the Kievan metropolitanate XVII-XVIII centuries. In Intrepido Pastori. Науковий збірник на честь блаженнійшого патріярха Йосича в40-ліття вступлення на Галицький престіл, 1.11.1944. Rome: Universitas Catholica Ucrainorum S. Clementis Papae, pp. 261-75.

Stern, Dieter Hubert. 2000. Die Liederhandschrift F 19-233 (15) der Bibliothek der Litauischen Akademie der Wissenschaften. Cologne, Weimar and Vienna: Böhlau.

Stern, Dieter. 2021. Ruthenian devotional songs as collectors' items? East-West: Journal of Ukrainian Studies 8. in press.

Ščurat, Vasyl'. 1908a. Ізстудій над почаївським Богогласником. L'viv: Nyva.

Ščrat, Vasyl'. 1908b. Ізстарої галицької лїтератури. ЗапискиНаукового Товариства ім. Шевченка 81: 181-88.

Ščurat, Vasyl'. 1910. Маріинський культ на українських земля $x$ давної польської держави. L'viv: Nyva.

Tazbir, Janusz. 1984. Różnowiercy polscy wobec kultu maryjnego. Studia Claromontana 5: 224-46.

Tazbir, Janusz. 2017. From Antemurale to Przedmurze, the History of the Term. Odrodzenie i reformacja w Polsce 61: 67-87. [CrossRef]

Trajdos, Tadeusz M. 1984. Kult wizerunków maryjnych na ziemiach ruskich Korony i Litwy drugiej połowy XIV i pierwszej połowy XV w. w społecznościach katolickiej i prawosławnej. Studia Claramontana 5: 127-47. 
Trześniewski, Grzegorz. 1767. Ozdoba y oborona ukraińskich krajów, przecudowna w Berdyczowskim obrazie Maryi watykańskiemi koronami od Benedykta XIV papieża z pobożney hoyności własnym Jego kosztem sprozadzonemi, przez ręce \{ . . \} Kajetana Ignacego Sottyka, krakowwskiego, na ten czas kijowskiego biskupa \{... \} w roku 1756, dnia 16 miesiaca lipca ukoronowana, to jest opisanie teyże odprawioney koronacji na dwie części rozdzieloney. Berdyczów: Drukarnia Karmelu Fortecy NMP.

Wereda, Dorota. 2018. Koronacje wizerunków maryjnych w Cerkwi unickiej. In Koronacje wizerunku Matki Boskiej na przestrzeni dziejów. Edited by Ewelina Dziewońska-Chudy and Maciej Trąbski. Częstochowa and Warsaw: Uniwersytet HumanistycznoPrzyrodniczy im. Jana Długosza w Częstochowie, pp. 67-79.

Žeňuch, Peter. 2006. Kyrillische paraliturgische Lieder. Edition des handschriftlichen Liedguts im ehemaligen Bistum von Mukačevo im 18. und 19. Jahrhundert. Cologne, Weimar and Vienna: Böhlau. 